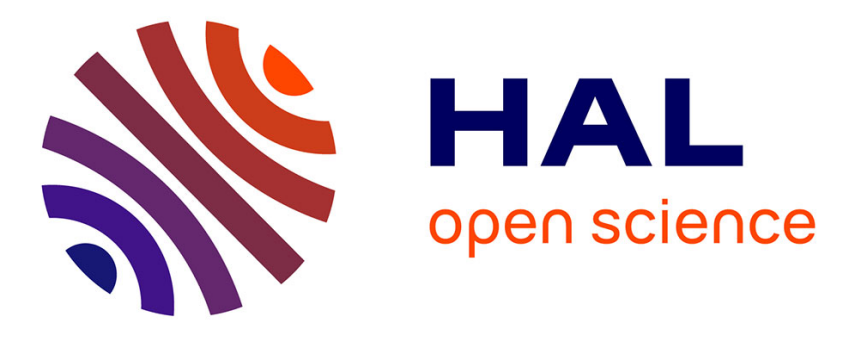

\title{
Antiviral activity of flexibilane and tigliane diterpenoids from Stillingia lineata
}

Florent Olivon, Héliciane Palenzuela, Emmanuelle Girard-Valenciennes, Johan

Neyts, Christophe Pannecouque, Fanny Roussi, Isabelle Grondin, Pieter

Leyssen, Marc Litaudon

\section{To cite this version:}

Florent Olivon, Héliciane Palenzuela, Emmanuelle Girard-Valenciennes, Johan Neyts, Christophe Pannecouque, et al.. Antiviral activity of flexibilane and tigliane diterpenoids from Stillingia lineata. Journal of Natural Products, 2015, 78 (5), pp.1119-1128. 10.1021/acs.jnatprod.5b00116 . hal-01163302

\section{HAL Id: hal-01163302 \\ https://hal.science/hal-01163302}

Submitted on 16 Nov 2016

HAL is a multi-disciplinary open access archive for the deposit and dissemination of scientific research documents, whether they are published or not. The documents may come from teaching and research institutions in France or abroad, or from public or private research centers.
L'archive ouverte pluridisciplinaire HAL, est destinée au dépôt et à la diffusion de documents scientifiques de niveau recherche, publiés ou non, émanant des établissements d'enseignement et de recherche français ou étrangers, des laboratoires publics ou privés. 


\title{
Antiviral Activity of Flexibilane and Tigliane Diterpenoids from Stillingia lineata
}

Florent Olivon, ${ }^{\dagger}$ Héliciane Palenzuela, ${ }^{\dagger}$ Emmanuelle Girard-Valenciennes, ${ }^{\dagger}$ Johan Neyts, ${ }^{\S}$ Christophe Pannecouque, ${ }^{\S}$ Fanny Roussi, ${ }^{\dagger}$ Isabelle Grondin,,${ }^{\dagger}$ Pieter Leyssen, ${ }^{\S}$ and Marc Litaudon ${ }^{*}, \dagger$

†Institut de Chimie des Substances Naturelles, CNRS-ICSN, UPR 2301, Université Paris-Sud, 91198, Gif-sur-Yvette, France

${ }^{\ddagger}$ Laboratoire de Chimie des Substances Naturelles et des Sciences des Aliments (LCSNSA), Universite de La Réunion, 15, Avenue René Cassin, CS 92003-97744 Saint-Denis Cedex 9, France

$\S$ Laboratory for Virology and Experimental Chemotherapy, Rega Institute for Medical Research, KU Leuven Minderbroedersstraat 10,B-3000 Leuven, Belgium

\begin{abstract}
In an effort to identify new potent and selective inhibitors of chikungunya virus and HIV-1 and HIV-2 virus replication, the endemic Mascarene species Stillingia lineata was investigated. LC/MS and bioassay-guided purification of the EtOAc leaf extract using a chikungunya virus-cell-based assay led to the isolation of six new (4-9) and three known (1-3) tonantzitlolones possessing the rare $\mathrm{C}_{20}$-flexibilane skeleton, along with tonantzitloic acid (10), a new linear diterpenoid, and three new $(11,13$, and 15) and two known (12 and 14) tigliane-type diterpenoids. The planar structures of the new compounds and their relative configurations were determined by spectroscopic analysis, and their absolute

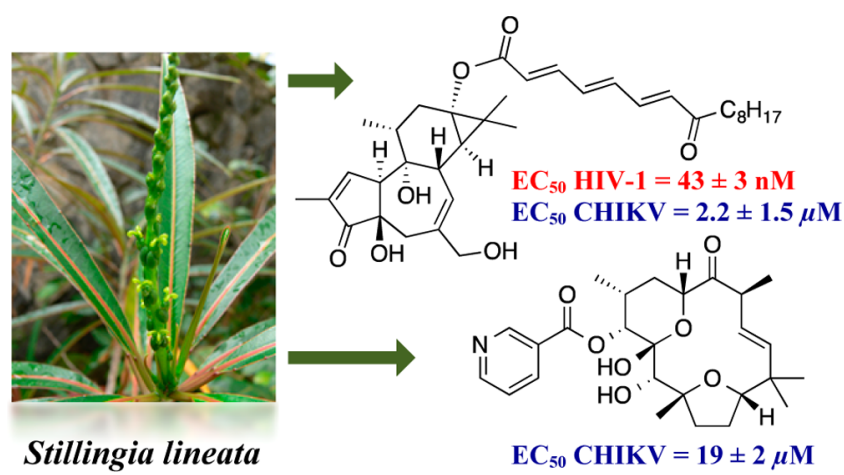
configurations were determined through comparison with literature data and from biogenetic considerations. These compounds were investigated for selective antiviral activity against chikungunya virus (CHIKV), Semliki Forest virus, Sindbis virus, and, for compounds 11-15, the HIV-1 and HIV-2 viruses. Compounds 12-15 were found to be the most potent and are selective inhibitors of CHIKV, HIV-1, and HIV-2 replication. In particular, compound 14 inhibited CHIKV replication with an $\mathrm{EC}_{50}$ value of $1.2 \mu \mathrm{M}$ on CHIKV and a selectivity index of $>240$, while compound 15 inhibited HIV-1 and HIV-2 with $\mathrm{EC}_{50}$ values of 0.043 and $0.018 \mu \mathrm{M}$, respectively. It was demonstrated further that potency and selectivity are sensitive to the substitution pattern on the tigliane skeleton. The cytotoxic activities of compounds 1-10 were evaluated against the HCT-116, MCF-7, and PC3 cancer cell lines.
\end{abstract}

$\mathrm{C}$ hikungunya virus (CHIKV) is an alphavirus of the family Togaviridae that causes an acute illness associated with severe morbidity (virus-induced arthralgia, fever, myalgia, and rash). It is transmitted by virus-carrying Aedes mosquitoes (in particular, A. aegypti and A. albopictus). A recent resurgence of this disease and large-scale epidemics in Africa, the Indian subcontinent, Southeast Asia, and lately also South and Central America are probably linked to climate change, allowing mosquito vectors to thrive at latitudes and locations that they previously could not reach. ${ }^{1,2}$ Currently, no specific antiviral therapy is available, and treatment is focused on relief of symptoms. 3,4

In an effort to identify novel inhibitors of CHIKV replication, several species were studied earlier of the family Euphorbiaceae, namely, Trigonostemon cherrieri, ${ }^{5-7} T$. howii, ${ }^{8}$ Croton mauritianus, ${ }^{9}$ and Euphorbia amygdaloides. ${ }^{10}$ This work has led to the isolation of several daphnane-, jatrophane-, and tigliane-type diterpenoids, and 12-O-tetradecanoylphorbol-13-acetate (TPA) was found to be the most potent and selective inhibitor of $\mathrm{CHIKV}$ replication, with an $\mathrm{EC}_{50}$ of $\sim 3 \mathrm{nM}$ and an SI near
$2000 .^{8}$ Owing to the wide range of their biological activities and their structural diversity, diterpenes of the Euphorbiaceae are key natural products for the discovery of promising molecules in antiviral or anticancer therapies. ${ }^{11-14}$ As an example, phorbol esters, which are protein kinase $\mathrm{C}$ modulators, ${ }^{15}$ are well known to exhibit interesting antiviral properties, inter alia, against human immunodeficiency virus. ${ }^{16-18}$

Recently, evaluation of the anti-CHIKV potential of 171 species from Réunion Island using a virus-cell-based assay led to the selection of, among others, Stillingia lineata (Lam.) Müll. Arg. for further chemical and biological studies. ${ }^{19}$ The genus Stillingia (Euphorbiaceae) is represented by 30 species distributed throughout Latin and North America and various islands of the Pacific and Indian Oceans. The leaf and latex extracts of some species have been reported to possess cytotoxic, $^{20}$ proteolytic, $^{21}$ and antifungal ${ }^{22}$ properties. The 


\section{Chart 1}
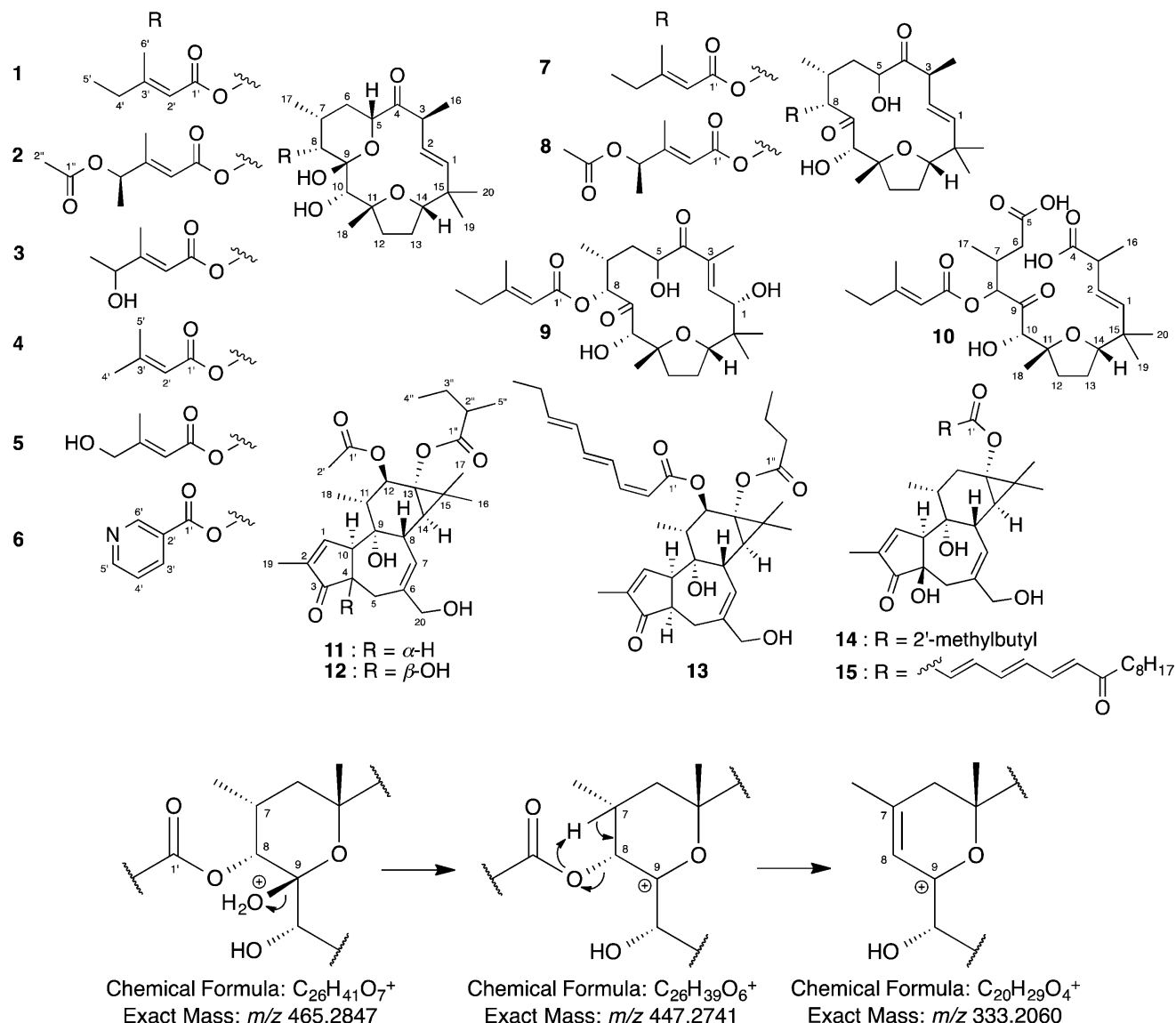

Figure 1. Proposed fragmentation mechanism for tonantzitlolones A and B (1 and 2).

roots of Stillingia sylvatica are used for preparing a therapeutic composition to treat various ailments such as syphilis, bronchitis, constipation, hemorroids, diseases of the skin, and cancer. ${ }^{23}$ Only three Stillingia species have been investigated chemically so far. ${ }^{22,24,25}$ From the roots of $S$. sylvatica, Adolf and Hecker reported the isolation of diterpene esters of the daphnane and tigliane types. ${ }^{24}$ More recently, Dräger and colleagues reported the isolation of two novel diterpenes, tonantzitlolones A and B, sharing the rare flexibilane backbone, from S. sanguinolenta. ${ }^{25}$ These compounds showed interesting cytotoxic activities against human kidney and breast cancer cell lines. ${ }^{26}$ Tonantzitlolone A was also isolated from the aerial parts of Sebastania macrocarpa, another Euphorbiaceae species collected in Brazil. ${ }^{27}$

In this paper are reported the LC-MS-guided isolation, structure elucidation, and anti-CHIKV properties of three known (1-3) and six new tonantzitlolones (4-9), tonantzitloic acid (10), and three new (11, 13, and 15) and two known tigliane diterpenes (12 and 14) isolated from the ethyl acetate extract of $S$. lineata leaves. The panel of viruses against which the antiviral activity of this compound class is studied was expanded with two additional members of the genus alphavirus (Sindbis virus: SINV; Semliki Forest virus: SFV), and for compounds 11-15 two members of the genus lentivirus (HIV1 and HIV-2 viruses).

\section{RESULTS AND DISCUSSION}

The leaves and bark of $S$. lineata were collected in November 2009 in the district of Langevin (Réunion Island). The EtOAc extracts obtained from the leaves and the bark of this species exhibited potent anti-CHIKV activities, with $\mathrm{EC}_{50}$ values of 0.25 and $0.80 \mu \mathrm{g} / \mathrm{mL}$, respectively. The chemical study of the EtOAc bark extract afforded three tonantzitlolones (1-3), of which 4 '-acetoxytonantzitlolone (2) exhibited moderate activity on CHIKV replication. ${ }^{28}$ With the aim of discovering additional members of this chemical series in this leaf EtOAc extract, a preliminary LC-HRESIMS study in the positive-ion mode was performed on the previously isolated tonantzitlolones $\mathrm{A}$ and $\mathrm{B}$ (1 and 2). The pseudomolecular ion peaks $[\mathrm{M}+\mathrm{Na}]^{+}$and $[\mathrm{M}$ $\left.+\mathrm{H}-\mathrm{H}_{2} \mathrm{O}\right]^{+}$together with a fragment ion at $\mathrm{m} / z 333.2066$ $\left(\mathrm{C}_{20} \mathrm{H}_{29} \mathrm{O}_{4}\right)$ were observed for both compounds. The latter corresponds to the loss of the side chain according to the fragmentation hypothesis depicted in Figure 1. The detection of this typical fragment ion is particularly interesting since it can be related to compounds that share the same $\mathrm{C}_{20}$-flexibilane macrocycle and can represent a qualitative marker for the presence of such compounds in extracts of $S$. lineata leaves.

The EtOAc leaf extract of $S$. lineata was defatted by a liquid/ liquid partition using acetonitrile and $n$-heptane and then subjected to normal-phase flash chromatography. All fractions were submitted to the previously mentioned LC-HRESIMS analysis. These experiments were shown to be particularly efficient and gave reliable ionizations, and all compounds showing an ion at $m / z 333.2066$ in their mass spectrum were isolated systematically. However, compound 6, with a nicotinate moiety, and compound 9 showed no such fragmentation. 
Table 1. NMR Spectroscopic Data $\left(\mathrm{CDCl}_{3}\right)$ for Compounds 4-10

\begin{tabular}{|c|c|c|c|c|c|c|c|c|c|c|c|}
\hline \multirow[b]{2}{*}{ position } & \multicolumn{3}{|c|}{ tonantzitlolone D (4) } & \multicolumn{3}{|c|}{ tonantzitlolone $\mathrm{E}(5)$} & \multicolumn{3}{|c|}{ tonantzitlolone $\mathrm{F}(6)$} & \multicolumn{2}{|c|}{ tonantzitlolone G (7) } \\
\hline & $\delta_{\mathrm{C}}$ & \multicolumn{2}{|c|}{$\delta_{\mathrm{H}}(J$ in $\mathrm{Hz})$} & $\delta_{\mathrm{C}}$ & \multicolumn{2}{|l|}{$\delta_{\mathrm{H}}(J$ in $\mathrm{Hz})$} & $\delta_{\mathrm{C}}$ & \multicolumn{2}{|l|}{$\delta_{\mathrm{H}}(J$ in $\mathrm{Hz})$} & $\delta_{\mathrm{C}}$ & $\delta_{\mathrm{H}}(J$ in $\mathrm{Hz})$ \\
\hline 1 & 140.3 & \multicolumn{2}{|c|}{$5.82 \mathrm{~d}(15.2)$} & 140.3 & \multicolumn{2}{|l|}{$5.82 \mathrm{~d}(15.2)$} & 140.2 & \multicolumn{2}{|l|}{$5.82 \mathrm{~d}(15.2)$} & 138.4 & $5.52 \mathrm{~d}(15.7)$ \\
\hline 2 & 126.9 & \multicolumn{2}{|c|}{$5.20 \mathrm{dd}(15.2,9.8)$} & 126.9 & \multicolumn{2}{|l|}{$5.20 \mathrm{dd}(15.2,9.7)$} & 127.2 & \multicolumn{2}{|l|}{$5.26 \mathrm{dd}(15.2,9.6)$} & 128.1 & $5.70 \mathrm{dd}(15.7,8.7)$ \\
\hline 3 & 49.7 & $3.31 \mathrm{~d}$ & $6.7)$ & 49.7 & $3.32 \mathrm{dq}(9.7,6.8)$ & & 49.8 & $3.34 \mathrm{dq}(9.6,6.8)$ & & 47.4 & $3.32 \mathrm{dq}(8.7,6.8)$ \\
\hline 4 & 211.7 & & & 211.6 & & & 211.1 & & & 214.0 & \\
\hline 5 & 74.3 & $4.59 \mathrm{~d}$ & , 2.7) & 74.4 & $4.59 \mathrm{dd}(11.8,2.5)$ & & 74.4 & $4.69 \mathrm{dd}(11.8,2.7)$ & & 75.9 & 4.37 brdd $(5.5,4.4)$ \\
\hline $6 \alpha$ & 28.9 & $1.33 \mathrm{n}$ & & 28.9 & $1.33 \mathrm{~m}^{a}$ & & 29.2 & 1.45 ddd $(13.6,12.8$ & 1.8) & 34.7 & $\begin{array}{l}1.91 \text { ddd }(15.2,4.4 \text {, } \\
3.2)\end{array}$ \\
\hline $6 \beta$ & & $1.82 \mathrm{~d}$ & $.5,4.0,2.7)$ & & $1.83 \mathrm{ddd}(13.6,4.0$, & & & $1.93 \mathrm{~m}^{a}$ & & & $1.98 \mathrm{~m}$ \\
\hline 7 & 29.2 & $2.29 \mathrm{n}$ & & 29.1 & $2.30 \mathrm{~m}$ & & 29.5 & $2.45 \mathrm{~m}$ & & 29.8 & $2.06 \mathrm{~m}$ \\
\hline 8 & 73.2 & $4.86 \mathrm{~d}$ & & 73.5 & $4.87 \mathrm{~d}(2.2)$ & & 75.6 & $5.11 \mathrm{~d}(2.4)$ & & 80.2 & $5.38 \mathrm{~d}(3.3)$ \\
\hline 9 & 97.2 & & & 97.2 & & & 97.2 & & & 208.6 & \\
\hline $\mathrm{OH}-9$ & & $5.62 \mathrm{~s}$ & & & $5.61 \mathrm{~s}$ & & & $5.73 \mathrm{~s}$ & & & \\
\hline 10 & 78.3 & $3.38 \mathrm{~d}$ & & 78.4 & $3.38 \mathrm{~s}$ & & 78.6 & $3.45 \mathrm{~d}(7.3)$ & & 78.8 & $4.35 \mathrm{~s}$ \\
\hline $\mathrm{OH}-10$ & & $3.12 \mathrm{~d}$ & & & $3.23 \mathrm{brs}$ & & & $3.12 \mathrm{~d}(7.3)$ & & & \\
\hline 11 & 87.7 & & & 87.7 & & & 87.9 & & & 85.0 & \\
\hline $12 \alpha$ & 37.5 & $2.40 \mathrm{~d}$ & , 7.6) & 37.5 & $2.36 \mathrm{dd}(12.6,7.6)$ & & 37.5 & $2.37 \mathrm{dd}(12.6,7.7)$ & & 32.9 & $1.75 \mathrm{~m}^{a}$ \\
\hline $12 \beta$ & & $1.51 \mathrm{~d}$ & $4,12.4,7.2)$ & & 1.51 ddd $(12.6,12$. & 7.4) & & 1.50 ddd $(12.6,12.2$ & & & $1.65 \mathrm{dd}(9.2,8.1)$ \\
\hline $13 \alpha$ & 28.2 & $\begin{array}{l}2.00 \mathrm{~d} \\
7.6)\end{array}$ & 2.4, 12.0, 11.3, & 28.2 & $\begin{array}{l}1.99 \text { dddd }(12.3,12 \\
7.6)\end{array}$ & 11.3, & 28.3 & $\begin{array}{l}1.95 \text { dddd }(12.2,11 \text {. } \\
7.7)\end{array}$ & 11.3, & 25.5 & $1.75 \mathrm{~m}^{a}$ \\
\hline $13 \beta$ & & $1.73 \mathrm{~d}$ & $.0,7.2,5.0)$ & & 1.73 ddd $(12.0,7.4$ & & & 1.74 ddd $(11.8,7.3$ & & & $1.87 \mathrm{~m}^{a}$ \\
\hline 14 & 89.0 & $3.74 \mathrm{~d}$ & , 5.0) & 89.0 & $3.74 \mathrm{dd}(11.3,5.0)$ & & 89.1 & $3.75 \mathrm{dd}(11.3,5.1)$ & & 87.1 & $3.74 \mathrm{dd}(7.3,6.5)$ \\
\hline 15 & 38.9 & & & 38.9 & & & 39.0 & & & 39.7 & \\
\hline 16 & 16.2 & $1.08 \mathrm{~d}$ & & 16.2 & $1.08 \mathrm{~d}(6.8)$ & & 16.3 & $1.14 \mathrm{~d}(6.8)$ & & 20.1 & $1.18 \mathrm{~d}(6.8)$ \\
\hline 17 & 17.2 & $0.81 \mathrm{~d}$ & & 17.2 & $0.82 \mathrm{~d}(6.8)$ & & 17.3 & $0.89 \mathrm{~d}(7.0)$ & & 17.3 & $1.02 \mathrm{~d}(6.9)$ \\
\hline 18 & 28.3 & $1.34 \mathrm{~s}$ & & 28.3 & $1.34 \mathrm{~s}$ & & 28.4 & $1.37 \mathrm{~s}$ & & 23.9 & $1.23 \mathrm{~s}$ \\
\hline 19 & 25.6 & $0.87 \mathrm{~s}$ & & 25.6 & $0.88 \mathrm{~s}$ & & 25.7 & $0.90 \mathrm{~s}$ & & 25.6 & $0.85 \mathrm{~s}$ \\
\hline 20 & 25.3 & $1.10 \mathrm{~s}$ & & 25.3 & $1.10 \mathrm{~s}$ & & 25.3 & $1.14 \mathrm{~s}$ & & 24.6 & $1.06 \mathrm{~s}$ \\
\hline $1^{\prime}$ & 166.4 & & & 166.5 & & & 165.4 & & & 165.3 & \\
\hline $2^{\prime}$ & 115.6 & $5.69 \mathrm{~s}$ & & 112.9 & $6.01 \mathrm{~s}$ & & 126.1 & & & 113.5 & $5.67 \mathrm{~s}$ \\
\hline $3^{\prime}$ & 158.6 & & & 159.4 & & & 137.5 & 8.27 brd (7.7) & & 163.8 & \\
\hline $4^{\prime}$ & 27.9 & $1.86 \mathrm{~s}$ & & 67.2 & $4.11 \mathrm{~s}$ & & 123.6 & $7.38 \mathrm{dd}(7.7,4.6)$ & & 34.0 & $2.15 \mathrm{q}(7.5)$ \\
\hline $5^{\prime}$ & 20.6 & $2.14 \mathrm{~s}$ & & 16.0 & $2.06 \mathrm{~s}$ & & 153.8 & $8.76 \mathrm{~d}(4.6)$ & & 12.0 & $1.05 \mathrm{t}(7.5)$ \\
\hline $6^{\prime}$ & & & & & & & 151.4 & $9.22 \mathrm{~s}$ & & 19.4 & $2.13 \mathrm{~s}$ \\
\hline & & & tzitlolone H (8 & & & tonantzi & olone I & & & tonantzi & tloic acid (10) \\
\hline position & & $\delta_{\mathrm{C}}$ & $\delta_{\mathrm{H}}(J$ in & & $\delta_{\mathrm{C}}$ & & $\delta_{\mathrm{H}}(J$ & $\mathrm{n} \mathrm{Hz})$ & $\delta_{\mathrm{C}}$ & & $\delta_{\mathrm{H}}(J$ in $\mathrm{Hz})$ \\
\hline 1 & & 138.1 & $5.51 \mathrm{~d}(15.7)$ & & 76.4 & $4.17 \mathrm{~d}$ & (9.5) & & 136.3 & & $5.55 \mathrm{~d}(15.9)$ \\
\hline 2 & & 128.2 & $5.71 \mathrm{dd}(15.7$ & & 144.5 & $6.32 \mathrm{~d}$ & $(9.5)$ & & 128.2 & & $5.48 \mathrm{dd}(15.9,6.6)$ \\
\hline 3 & & 47.4 & $3.33 \mathrm{dq}(8.8$ & & 133.0 & & & & 42.7 & & $3.13 \mathrm{qd}(7.0,6.6)$ \\
\hline 4 & & 213.9 & & & 203.3 & & & & 180.9 & & \\
\hline 5 & & 75.8 & 4.38 brs & & 71.8 & $5.03 \mathrm{~m}$ & & & 179.4 & & \\
\hline $\mathrm{OH}-5$ & & & & & & $3.86 \mathrm{~b}$ & $(3.9)$ & & & & \\
\hline $6 \alpha$ & & 34.6 & $1.91 \mathrm{~m}^{a}$ & & 34.6 & $2.13 \mathrm{~m}$ & & & 35.8 & & $2.20 \mathrm{~m}^{a}$ \\
\hline $6 \beta$ & & & $1.99 \mathrm{ddd}(7.0$ & $6.6,6.0)$ & & & & & & & $2.36 \mathrm{dd}(15.7,5.9)$ \\
\hline 7 & & 29.7 & $2.01 \mathrm{~m}$ & & 29.5 & $2.02 \mathrm{~m}$ & & & 31.0 & & $3.11 \mathrm{~m}$ \\
\hline 8 & & 80.6 & $5.39 \mathrm{~d}(2.9)$ & & 79.9 & $4.82 \mathrm{~d}$ & $(1.2)$ & & 79.5 & & 5.50 brs \\
\hline 9 & & 208.5 & & & 207.0 & & & & 206.4 & & \\
\hline 10 & & 78.5 & $4.35 \mathrm{~d}(4.9)$ & & 82.9 & $4.33 \mathrm{~d}$ & (4.9) & & 81.2 & & $3.88 \mathrm{~s}$ \\
\hline $\mathrm{OH}-10$ & & & $3.10 \mathrm{~d}(4.9)$ & & & $3.78 \mathrm{~d}$ & (4.9) & & & & \\
\hline 11 & & 85.0 & & & 85.8 & & & & 85.4 & & \\
\hline $12 \alpha$ & & 32.7 & $1.74 \mathrm{~m}^{a}$ & & 37.8 & $2.47 \mathrm{~d}$ & $(12.5$, & & 34.8 & & $2.18 \mathrm{~m}^{a}$ \\
\hline $12 \beta$ & & & $1.64 \mathrm{~m}$ & & & $1.46 \mathrm{~d}$ & $\mathrm{~d}(12.5$, & $12.2,7.3)$ & & & $1.68 \mathrm{~m}^{a}$ \\
\hline $13 \alpha$ & & 25.4 & $1.72 \mathrm{~m}^{a}$ & & 29.7 & $1.84 \mathrm{~d}$ & $\mathrm{dd}(12.2$ & $11.8,11.4,8.0)$ & 27.0 & & $1.68 \mathrm{~m}^{a}$ \\
\hline $13 \beta$ & & & $1.87 \mathrm{~m}^{a}$ & & & $1.68 \mathrm{~d}$ & d (11.8, & $7.3,4.5)$ & & & $1.85 \mathrm{~m}$ \\
\hline 14 & & 87.1 & $3.73 \mathrm{dd}(7.3$ & & 84.9 & $3.58 \mathrm{~d}$ & $(11.4$, & & 87.1 & & $3.73 \mathrm{dd}(7.6,6.6)$ \\
\hline 15 & & 39.6 & & & 43.9 & & & & 39.3 & & \\
\hline 16 & & 20.2 & $1.18 \mathrm{~d}(6.8)$ & & 12.4 & $1.87 \mathrm{~s}$ & & & 17.2 & & $1.24 \mathrm{~d}(7.0)$ \\
\hline 17 & & 17.3 & $1.01 \mathrm{~d}(6.4)$ & & 17.0 & $0.99 \mathrm{~d}$ & $(6.9)$ & & 19.2 & & $1.11 \mathrm{~d}(6.9)$ \\
\hline 18 & & 23.9 & $1.22 \mathrm{~s}$ & & 27.1 & $1.32 \mathrm{~s}$ & & & 20.5 & & $1.19 \mathrm{~s}$ \\
\hline 19 & & 25.8 & $0.84 \mathrm{~s}$ & & 12.2 & $0.81 \mathrm{~s}$ & & & 24.6 & & $0.89 \mathrm{~s}$ \\
\hline
\end{tabular}


Table 1. continued

\begin{tabular}{|c|c|c|c|c|c|c|}
\hline \multirow[b]{2}{*}{ position } & \multicolumn{2}{|c|}{ tonantzitlolone $\mathrm{H}(\mathbf{8})$} & \multicolumn{2}{|r|}{ tonantzitlolone I (9) } & \multicolumn{2}{|c|}{ tonantzitloic acid (10) } \\
\hline & $\delta_{\mathrm{C}}$ & $\delta_{\mathrm{H}}(J$ in $\mathrm{Hz})$ & $\delta_{\mathrm{C}}$ & $\delta_{\mathrm{H}}(J$ in $\mathrm{Hz})$ & $\delta_{\mathrm{C}}$ & $\delta_{\mathrm{H}}(J$ in $\mathrm{Hz})$ \\
\hline 20 & 24.6 & $1.06 \mathrm{~s}$ & 23.7 & $0.96 \mathrm{~s}$ & 26.2 & $1.08 \mathrm{~s}$ \\
\hline $1^{\prime}$ & 164.7 & & 167.0 & & 166.0 & \\
\hline $2^{\prime}$ & 114.2 & $5.87 \mathrm{brs}$ & 112.8 & $5.69 \mathrm{~s}$ & 113.8 & $5.74 \mathrm{~s}$ \\
\hline $3^{\prime}$ & 158.6 & & 164.9 & & 163.2 & \\
\hline $4^{\prime}$ & 73.7 & $5.23 q(6.6)$ & 34.1 & $2.15 \mathrm{q}^{a}(7.4)$ & 34.0 & $2.16 \mathrm{q}(7.5)$ \\
\hline $5^{\prime}$ & 19.4 & $1.33 \mathrm{~d}(6.6)$ & 12.0 & $1.04 \mathrm{t}(7.4)$ & 12.0 & $1.05 \mathrm{t}(7.5)$ \\
\hline $6^{\prime}$ & 15.8 & $2.11 \mathrm{brs}$ & 19.4 & $2.08 \mathrm{~s}$ & 19.4 & $2.10 \mathrm{~s}$ \\
\hline $1^{\prime \prime}$ & 170.2 & & & & & \\
\hline $2^{\prime \prime}$ & 21.5 & $2.08 \mathrm{~s}$ & & & & \\
\hline
\end{tabular}

In parallel, the anti-CHIKV activity of all fractions was assessed, leading to the isolation of compounds $10-15$. The ${ }^{1} \mathrm{H}$ and ${ }^{13} \mathrm{C}$ NMR data of compounds 4 to 10 and of 11, 13, and 15 are reported in Tables 1 and 2, respectively. Tonantzitlolones A-C (1-3) were identified through comparison with NMR data reported in the literature, ${ }^{25,28}$ and their absolute configurations were assigned by ROESY correlations and comparison of specific rotation values with those reported in the literature. The $R$ configuration of the stereogenic center $C$ $4^{\prime}$ of compound 2 was determined by comparison of the NMR data given by Busch et al., ${ }^{25}$ but the configuration of C-4' of compound 3, postulated as $R$, remains uncertain.

Compound 4 showed a pseudomolecular ion at $\mathrm{m} / \mathrm{z}$ 473.2523 $[\mathrm{M}+\mathrm{Na}]^{+}$(calcd 473.2515) in the HRESIMS, corresponding to the molecular formula $\mathrm{C}_{25} \mathrm{H}_{38} \mathrm{O}_{7}$. From this formula and its spectroscopic data, closely comparable to those of 1, it was apparent that 4 has a similar structure but an aliphatic side chain that possesses two methyl groups instead of one methyl group and one ethyl group as for compound $\mathbf{1}$. Besides the characteristic macrocyclic moiety, the analysis of the ${ }^{1} \mathrm{H}$ NMR spectrum indicated the loss of the proton signal at $2.15 \mathrm{ppm}\left(\mathrm{CH}_{2}-4^{\prime}, \mathrm{q}\right.$ in $\left.\mathbf{1}\right)$. Instead, a methyl group at $\delta_{\mathrm{H}} 1.86$ $\left(\mathrm{CH}_{3}-4^{\prime}, \mathrm{s}\right)$, which correlated with $\mathrm{C}-2^{\prime}, \mathrm{C}-3^{\prime}$, and $\mathrm{C}-5^{\prime}\left(\delta_{\mathrm{C}}\right.$ $115.6,158.6$, and 20.6, respectively) in the HMBC spectrum, suggested a senecioate moiety, linked to the macrocycle at C-8 by observation of a correlation from $\mathrm{H}-8$ to the $\mathrm{C}-\mathrm{1}^{\prime}$ carbonyl (Figure 2). The relative configuration of 4 was defined by the inspection of the ROESY spectrum (Figure 3). Correlations between $\mathrm{H}-5 / \mathrm{H}-6 \beta / \mathrm{H}-7 / \mathrm{H}-8 / \mathrm{H}-10 / \mathrm{H}-18 / \mathrm{H}-12 \beta / \mathrm{H}-13 \beta / \mathrm{H}-$ 14 suggested the $\beta$-orientation of these protons. A specific rotation value $\left(+120, c 0.1, \mathrm{CHCl}_{3}\right)$ of the same sign and magnitude as was obtained for compound 1 suggested that the absolute configuration should be the same as for tonantzitlolone A. Compound $\mathbf{4}$ was given the trivial name tonantzitlolone D.

Compound 5 (tonantzitlolone $\mathrm{E}$ ) was assigned a molecular formula of $\mathrm{C}_{25} \mathrm{H}_{38} \mathrm{O}_{8}$ on the basis of its ${ }^{13} \mathrm{C} \mathrm{NMR}$ and HRESIMS data, suggesting the presence of an additional hydroxy group when compared with compound 4 . In the $\mathrm{HMBC}$ spectrum, correlations from $\mathrm{H}_{2}-4^{\prime}\left(\delta_{\mathrm{H}} 4.11\right)$ to C-2', C$3^{\prime}$, and $\mathrm{C}-5^{\prime}$ suggested the presence of a hydroxymethylene group at C-3' to afford the $4^{\prime}$-hydroxysenecioate unit, linked to the macrocycle at C- 8 by observation of a correlation from $\mathrm{H}-8$ to carbonyl C-1'. Analysis of the ROESY spectrum and comparison with data reported indicated the same relative and absolute configurations to compound 4 .

Compound 6 (tonantzitlolone $\mathrm{F}$ ) gave a molecular formula of $\mathrm{C}_{26} \mathrm{H}_{35} \mathrm{NO}_{7}$, as supported by HRESIMS, showing a $[\mathrm{M}+$
$\mathrm{H}]^{+}$ion peak at $m / z 474.2461$ (calcd for $\mathrm{C}_{26} \mathrm{H}_{36} \mathrm{NO}_{7}$, 474.2492). The ${ }^{1} \mathrm{H}$ and ${ }^{13} \mathrm{C}$ NMR data suggested that compounds 4 and $\mathbf{6}$ share the same flexibilane-type macrocyclic ring, but have a different side chain. The characteristic ${ }^{1} \mathrm{H}$ NMR signals at $\delta_{\mathrm{H}} 9.22\left(\mathrm{H}-6^{\prime}, \mathrm{s}\right), 8.76\left(\mathrm{H}-5^{\prime}, \mathrm{d}, 4.6 \mathrm{~Hz}\right), 8.27\left(\mathrm{H}-3^{\prime}\right.$, brd, $7.7 \mathrm{~Hz})$, and $7.38\left(\mathrm{H}-4^{\prime}, \mathrm{dd}, 7.7,4.6 \mathrm{~Hz}\right)$, together with HMBC cross-peaks from $\mathrm{H}-3^{\prime}, \mathrm{H}-6^{\prime}$, and $\mathrm{H}-8$ to the carbonyl $\mathrm{C}-1^{\prime}$ at $\delta_{\mathrm{C}} 165.4$, revealed the presence of a nicotinyl ester moiety attached at C-8 on the macrocycle. ${ }^{29}$ Due to a preferential ionization of nonbonding electrons of the nitrogen atom of the nicotinate moiety, the in-source fragmentation of 6 did not lead to the cleavage of the side chain, as for the other members of this chemical series. The relative and absolute configurations of 6 , similar to compound 4 , were determined by inspection of ROESY correlations and through analysis of specific rotation values.

The HRESIMS of compound 7 (tonantzitlolone G) showed a pseudomolecular ion $[\mathrm{M}+\mathrm{Na}]^{+}$at $\mathrm{m} / z 487.2664$ (calcd 487.2672), corresponding to the molecular formula $\mathrm{C}_{26} \mathrm{H}_{40} \mathrm{O}_{7}$, the same as for compound $\mathbf{1}$. However, different chemical shifts were observed in the ${ }^{1} \mathrm{H}$ and ${ }^{13} \mathrm{C}$ NMR spectra of compounds 1 and 7. Both compounds were found to possess the same methyl senecioate unit, but a different macrocycle could be deduced from the analysis of the 1D- and 2D-NMR spectra of 7. Indeed, the loss of the ${ }^{13} \mathrm{C}$ NMR acetal resonance $\left(\delta_{\mathrm{C}} 97.2\right.$ in 4-6), which was replaced by a carbonyl at C-9 $(\delta$ 208.6) that correlated in the HMBC spectrum with $\mathrm{H}-8\left(\delta_{\mathrm{H}} 5.38\right)$ and $\mathrm{H}$ $10\left(\delta_{\mathrm{H}} 4.35\right)$, and the presence of a hydroxy group at C-5 $\left(\delta_{\mathrm{H} / \mathrm{C}}\right.$ $4.37 / 75.9)$ were the most obvious modifications observed for compound 7. These data suggested the opening of the lactol ring, leading to a slightly different $\mathrm{C}-15$ macrocyclic moiety. Moreover, analysis of the NMR spectroscopic data of 7 (the key COSY and HMBC correlations are presented in Figure 2) indicated that 7 possesses the same $\mathrm{C}_{20}$-flexibilane macrocycle as tonantzitlolones 1-6. However, despite the presence of a strong ROESY correlation between $\mathrm{H}-5\left(\delta_{\mathrm{H}} 4.37\right)$ and $\mathrm{H}-3\left(\delta_{\mathrm{H}}\right.$ $3.32)$, the relative configuration of the $\mathrm{C}-5$ stereocenter remained ambiguous due to the flexibility of the macrocycle. The relative configurations of the other stereogenic centers were deduced from analysis of the ROESY spectrum (Figure 3). Compound 7 was named tonantzitlolone G.

Compound 8 (tonantztlolone $\mathrm{H}$ ) showed in the HRESIMS a pseudomolecular $[\mathrm{M}+\mathrm{Na}]^{+}$ion at $\mathrm{m} / z 545.2724$ (calcd for $\mathrm{C}_{28} \mathrm{H}_{42} \mathrm{O}_{9} \mathrm{Na}$, 545.2727), corresponding to the molecular formula $\mathrm{C}_{28} \mathrm{H}_{42} \mathrm{O}_{9}$. The molecular formulas of $\mathbf{2}$ and $\mathbf{8}$ are identical, and their ${ }^{1} \mathrm{H}$ and ${ }^{13} \mathrm{C}$ NMR data indicated that these compounds share the same $4^{\prime}$-acetoxymethylsenecioate side chain, but a different macrocycle. The NMR data related to the 
Table 2. NMR Spectroscopic Data $\left(\mathrm{CDCl}_{3}\right)$ for Compounds 11, 13, and 15

\begin{tabular}{|c|c|c|c|c|c|c|c|c|c|}
\hline \multirow[b]{2}{*}{ position } & \multicolumn{3}{|r|}{11} & \multicolumn{3}{|c|}{13} & \multicolumn{3}{|r|}{15} \\
\hline & $\delta_{\mathrm{C}}$ & & $\delta_{\mathrm{H}}(J$ in $\mathrm{Hz})$ & $\delta_{\mathrm{C}}$ & & $\delta_{\mathrm{H}}(J$ in $\mathrm{Hz})$ & $\delta_{\mathrm{C}}$ & & $\delta_{\mathrm{H}}(J$ in $\mathrm{Hz})$ \\
\hline 1 & 156.3 & $\mathrm{CH}$ & $7.01 \mathrm{~s}$ & 156.6 & $\mathrm{CH}$ & $7.04 \mathrm{~s}$ & 161.6 & $\mathrm{CH}$ & 7.58 brs \\
\hline 2 & 143.6 & $\mathrm{C}$ & & 143.5 & $\mathrm{C}$ & & 133.0 & $\mathrm{C}$ & \\
\hline 3 & 213.4 & $\mathrm{C}$ & & 213.8 & $\mathrm{C}$ & & 209.6 & $\mathrm{C}$ & \\
\hline 4 & 49.9 & $\mathrm{CH}$ & $2.77 \mathrm{~m}$ & 49.8 & $\mathrm{CH}$ & $2.78 \mathrm{~m}$ & 73.9 & $\mathrm{C}$ & \\
\hline $5 \alpha$ & 25.4 & $\mathrm{CH}_{2}$ & $2.46 \mathrm{dd}(15.5,5.0)$ & 25.2 & $\mathrm{CH}_{2}$ & $2.47 \mathrm{dd}(15.5,4.7)$ & 38.7 & $\mathrm{CH}_{2}$ & $2.45 \mathrm{~d}(19.0)$ \\
\hline $5 \beta$ & & & 3.43 br d (15.5) & & & $3.43 \mathrm{br} \mathrm{d}(15.5)$ & & & $2.51 \mathrm{~d}(19.0)$ \\
\hline 6 & 137.3 & $\mathrm{C}$ & & 137.0 & $\mathrm{C}$ & & 140.1 & $\mathrm{C}$ & \\
\hline 7 & 126.6 & $\mathrm{CH}$ & 5.09 brs & 126.9 & $\mathrm{CH}$ & 5.10 brs & 130.5 & $\mathrm{CH}$ & $5.66 \mathrm{~d}(4.6)$ \\
\hline 8 & 40.9 & $\mathrm{CH}$ & $1.93 \mathrm{brs}$ & 40.8 & $\mathrm{CH}$ & $1.93 \mathrm{brs}$ & 39.2 & $\mathrm{CH}$ & 3.00 brs \\
\hline 9 & 78.2 & $\mathrm{C}$ & & 78.2 & $\mathrm{C}$ & & 76.3 & $\mathrm{C}$ & \\
\hline OH-9 & & & $5.27 \mathrm{~s}$ & & & $5.30 \mathrm{~s}$ & & & \\
\hline 10 & 47.6 & $\mathrm{CH}$ & $3.48 \mathrm{~m}$ & 47.6 & $\mathrm{CH}$ & $3.49 \mathrm{~m}$ & 55.8 & $\mathrm{CH}$ & 3.26 brs \\
\hline 11 & 43.7 & $\mathrm{CH}$ & $1.65 \mathrm{dq}(10.4,6.4)$ & 43.6 & $\mathrm{CH}$ & $1.67 \mathrm{dq}(10.4,6.2)$ & 36.4 & $\mathrm{CH}$ & $1.96 \mathrm{dq}(6.8,6.0)$ \\
\hline $12 \alpha$ & 76.2 & $\mathrm{CH}$ & $5.41 \mathrm{~d}(10.4)$ & 74.9 & $\mathrm{CH}$ & $5.48 \mathrm{~d}(10.4)$ & 31.9 & $\mathrm{CH}$ & $1.57 \mathrm{~m}$ \\
\hline $12 \beta$ & & & & & & & & & $2.07 \mathrm{dd}(14.8,6.8)$ \\
\hline 13 & 65.0 & $\mathrm{C}$ & & 65.1 & $\mathrm{C}$ & & 63.9 & $\mathrm{C}$ & \\
\hline 14 & 37.5 & $\mathrm{CH}$ & $0.71 \mathrm{~d}(5.1)$ & 37.1 & $\mathrm{CH}$ & $0.74 \mathrm{~d}(5.1)$ & 32.8 & $\mathrm{CH}$ & $0.86 \mathrm{~m}$ \\
\hline 15 & 25.7 & $\mathrm{C}$ & & 25.4 & $\mathrm{C}$ & & 23.2 & $\mathrm{C}$ & \\
\hline 16 & 16.7 & $\mathrm{CH}_{3}$ & $1.17 \mathrm{~s}$ & 16.6 & $\mathrm{CH}_{3}$ & $1.18 \mathrm{~s}$ & 15.6 & $\mathrm{CH}_{3}$ & $1.06 \mathrm{~s}$ \\
\hline 17 & 24.4 & $\mathrm{CH}_{3}$ & $1.18 \mathrm{~s}$ & 24.4 & $\mathrm{CH}_{3}$ & $1.14 \mathrm{~s}$ & 23.5 & $\mathrm{CH}_{3}$ & $1.19 \mathrm{~s}$ \\
\hline 18 & 12.2 & $\mathrm{CH}_{3}$ & $1.06 \mathrm{~d}(6.4)$ & 12.2 & $\mathrm{CH}_{3}$ & $1.06 \mathrm{~d}(6.2)$ & 18.8 & $\mathrm{CH}_{3}$ & $0.86 \mathrm{~m}$ \\
\hline 19 & 10.5 & $\mathrm{CH}_{3}$ & $1.76 \mathrm{~s}$ & 10.5 & $\mathrm{CH}_{3}$ & $1.76 \mathrm{~s}$ & 10.4 & $\mathrm{CH}_{3}$ & $1.75 \mathrm{brs}$ \\
\hline $20 \mathrm{a}$ & 69.6 & $\mathrm{CH}_{2}$ & $3.88 \mathrm{~d}(12.4)$ & 69.5 & $\mathrm{CH}_{2}$ & $3.87 \mathrm{~d}(12.3)$ & 68.4 & $\mathrm{CH}_{2}$ & $3.95 \mathrm{~d}(12.8)$ \\
\hline $20 \mathrm{~b}$ & & & $4.00 \mathrm{~d}(12.4)$ & & & $4.00 \mathrm{~d}(12.3)$ & & & $4.02 \mathrm{~d}(12.8)$ \\
\hline $1^{\prime}$ & 170.7 & $\mathrm{C}$ & & 166.3 & $\mathrm{C}$ & & 168.6 & $\mathrm{C}$ & \\
\hline $2^{\prime}$ & 21.3 & $\mathrm{CH}_{3}$ & $2.10 \mathrm{~s}$ & 115.6 & $\mathrm{CH}$ & $5.60 \mathrm{~d}(11.3)$ & 124.0 & $\mathrm{CH}$ & $5.98 \mathrm{~d}(15.2)$ \\
\hline $3^{\prime}$ & & & & 146.1 & $\mathrm{CH}$ & $6.63 \mathrm{dd}(11.5,11.3)$ & 144.4 & $\mathrm{CH}$ & 7.33 ddd $(15.2,7.4,3.0)$ \\
\hline $4^{\prime}$ & & & & 126.6 & $\mathrm{CH}$ & $7.41 \mathrm{dd}(14.9,11.5)$ & 137.4 & $\mathrm{CH}$ & $6.64 \mathrm{dd}(7.4,3.0)$ \\
\hline $5^{\prime}$ & & & & 142.9 & $\mathrm{CH}$ & $6.48 \mathrm{dd}(14.9,10.9)$ & 138.8 & $\mathrm{CH}$ & $6.64 \mathrm{dd}(7.4,3.0)$ \\
\hline $6^{\prime}$ & & & & 130.5 & $\mathrm{CH}$ & $6.21 \mathrm{dd}(15.2,10.9)$ & 140.2 & $\mathrm{CH}$ & 7.17 ddd $(15.2,7.4,3.0)$ \\
\hline $7^{\prime}$ & & & & 141.3 & $\mathrm{CH}$ & $5.94 \mathrm{dt}(15.2,7.2)$ & 132.9 & $\mathrm{CH}$ & $6.31 \mathrm{~d}(15.2)$ \\
\hline $8^{\prime}$ & & & & 35.3 & $\mathrm{CH}_{2}$ & $2.11 \mathrm{td}(7.4,7.2)$ & 200.8 & $\mathrm{C}$ & \\
\hline $9^{\prime}$ & & & & 22.3 & $\mathrm{CH}_{2}$ & $1.42 \mathrm{tq}(7.4,7.4)$ & 41.5 & $\mathrm{CH}_{2}$ & $2.55 \mathrm{t}(7.5)$ \\
\hline $10^{\prime}$ & & & & 13.9 & $\mathrm{CH}_{3}$ & $0.89 \mathrm{t}(7.4)$ & 24.4 & $\mathrm{CH}_{2}$ & $1.59 \mathrm{~m}$ \\
\hline $11^{\prime}-13^{\prime}$ & & & & & & & 29.4 & $\mathrm{CH}_{2}$ & $1.20-1.27 \mathrm{~m}$ \\
\hline & & & & & & & 29.5 & $\mathrm{CH}_{2}$ & $1.20-1.27 \mathrm{~m}$ \\
\hline & & & & & & & 29.6 & $\mathrm{CH}_{2}$ & $1.20-1.27 \mathrm{~m}$ \\
\hline $14^{\prime}$ & & & & & & & 32.0 & $\mathrm{CH}_{2}$ & $1.20-1.27 \mathrm{~m}$ \\
\hline $15^{\prime}$ & & & & & & & 22.9 & $\mathrm{CH}_{2}$ & $1.20-1.27 \mathrm{~m}$ \\
\hline $16^{\prime}$ & & & & & & & 14.4 & $\mathrm{CH}_{3}$ & $1.85 \mathrm{t}(7.1)$ \\
\hline $1^{\prime \prime}$ & 178.8 & $\mathrm{C}$ & & 176.3 & $\mathrm{C}$ & & & & \\
\hline $2^{\prime \prime} \alpha$ & 41.5 & $\mathrm{CH}$ & $2.32 \mathrm{qt}(7.0,6.8)$ & 36.5 & $\mathrm{CH}_{2}$ & $2.27 \mathrm{~m}$ & & & \\
\hline $2^{\prime \prime} \beta$ & & & & & & $2.30 \mathrm{~m}$ & & & \\
\hline $3^{\prime \prime} \alpha$ & 26.3 & $\mathrm{CH}_{2}$ & $1.41 \mathrm{qdd}(7.5,6.8,6.8)$ & 18.3 & $\mathrm{CH}_{2}$ & 1.62 tq $(13.7,7.4)$ & & & \\
\hline $3^{\prime \prime} \beta$ & & & 1.70 qdd $(7.5,6.8,6.8)$ & & & & & & \\
\hline $4^{\prime \prime}$ & 11.9 & $\mathrm{CH}_{3}$ & $0.90 \mathrm{t}(7.5)$ & 13.9 & $\mathrm{CH}_{3}$ & $0.92 \mathrm{t}(7.4)$ & & & \\
\hline $5^{\prime \prime}$ & 16.4 & $\mathrm{CH}_{3}$ & $1.09 \mathrm{~d}(7.0)$ & & & & & & \\
\hline
\end{tabular}

macrocyclic moiety of $\mathbf{8}$ were found to be closely comparable to those of compound 7 , thus indicating that this part of these molecules is identical. The relative configuration of $\mathbf{8}$, similar to 7, was deduced from analysis of its ROESY spectrum, with the exception of $\mathrm{H}-5$, for which the orientation remains unknown.

The HRESIMS of compound 9 (tonantzitlolone I) showed a pseudomolecular $[\mathrm{M}+\mathrm{Na}]^{+}$ion peak at $\mathrm{m} / z 503.2635(\mathrm{calcd}$ 503.2621) corresponding to the molecular formula $\mathrm{C}_{26} \mathrm{H}_{40} \mathrm{O}_{8}$. From this formula and its NMR spectroscopic data, which were comparable to those of 7 , it was apparent that 9 has a structure similar to 7 , as characterized by the presence of a methyl senecioate moiety and a hydroxy ketone macrocycle, but with an additional hydroxy group at C-1 and the shift of the $\Delta^{1,2}$ double bond to positions C-2 and C-3. The shift of the double bond was supported by HMBC correlations between the methyl protons $\mathrm{H}_{3}-16\left(\delta_{\mathrm{H}} 1.87\right)$ and the olefinic carbons $\mathrm{C}-2$ and $\mathrm{C}-3\left(\delta_{\mathrm{C}} 144.5\right.$ and 133.0 , respectively) and carbonyl C-4 $\left(\delta_{\mathrm{C}}\right.$ 203.3). The $E$ configuration of the double bond was confirmed by the absence of any ROESY correlation between $\mathrm{H}-2$ and $\mathrm{H}-16$. The chemical shifts of $\mathrm{H} / \mathrm{C}-1\left(\delta_{\mathrm{H}} 4.17\right.$ and $\delta_{\mathrm{C}}$ 76.4) together with a COSY correlation between $\mathrm{H}-1$ and $\mathrm{H}-2$ indicated the presence of a hydroxy group at $\mathrm{C}-1$. The relative 

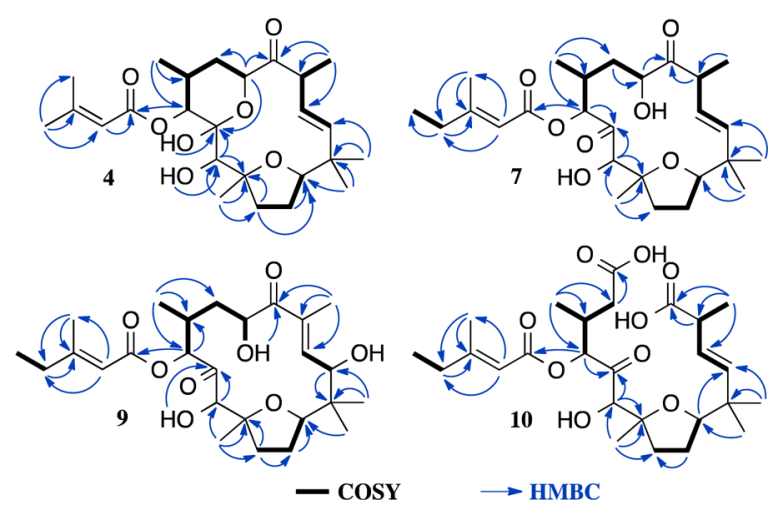

Figure 2. Key COSY (bold) and HMBC (blue arrows) correlations of compounds 4, 7, 9, and 10.

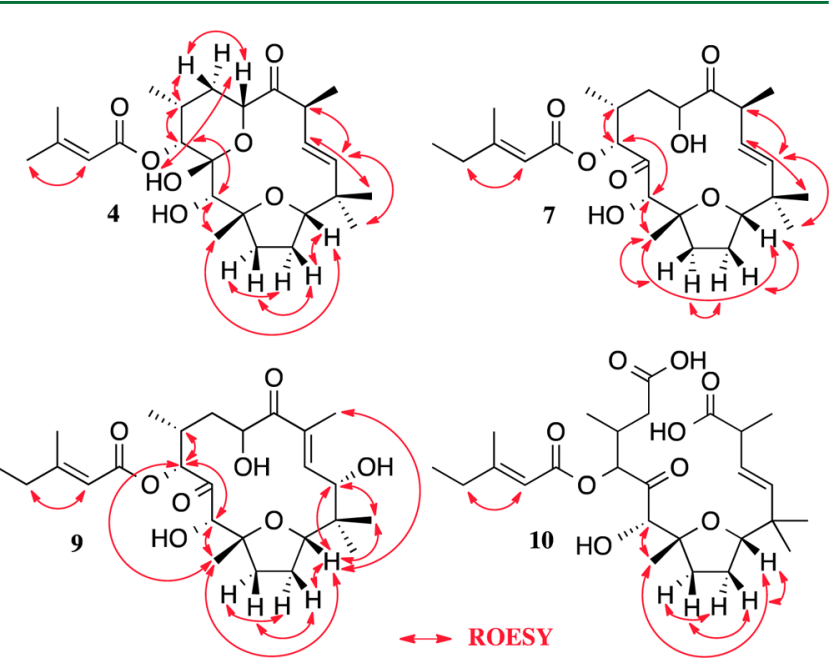

Figure 3. Key ROESY correlations (red arrows) of compounds 4, 7, 9, and 10.

configuration of 9 was deduced by analysis of the ROESY spectrum, but, as for compounds 7 and 8 , the orientation of $\mathrm{H}$ 5 remains uncertain due to the flexibility of the macrocycle. Key 2D-NMR correlations observed for compound 9 are shown in Figures 2 and 3 .

It should be noted that compounds 7-9 were isolated in trace quantities, whereas the corresponding cyclic hemiacetals, tonantzitlolones $\mathrm{A}$ and $\mathrm{B}$ ( $\mathbf{1}$ and $\mathbf{2})$, were isolated in large amounts. The six-membered cyclic hemiacetals are generally favored due to conformational effects and a fast hemiacetalforming reaction. However, LC/MS and ${ }^{1} \mathrm{H}$ NMR analysis of compounds $\mathbf{1}$ and 2 stored at $4{ }^{\circ} \mathrm{C}$ in DMSO for three months showed the presence of an equilibrium mixture of cyclic hemiacetal and hydroxy ketone forms, in approximately 75:25 and 45:55 ratio for $7 / 1$ and $8 / 2$ mixtures, respectively.

The HRESIMS of compound 10 showed a pseudomolecular ion peak $[\mathrm{M}+\mathrm{Na}]^{+}$at $\mathrm{m} / z 519.2557$ (calcd 519.2570), which, in conjunction with the ${ }^{13} \mathrm{C}$ NMR spectroscopic data, was consistent with a molecular formula, $\mathrm{C}_{26} \mathrm{H}_{40} \mathrm{O}_{9}$, indicating seven indices of hydrogen deficiency. An initial analysis of the $1 \mathrm{D}$ - and 2D-NMR spectroscopic data of compound $\mathbf{1 0}$ indicated its planar structure to be substantially different from previous tonantzitlolones. To facilitate the structural determination of compound 10, the carbon numbering was kept unchanged. Its ${ }^{13} \mathrm{C}$ NMR spectrum, when compared with compound 7, revealed the presence of resonances for two carboxylic acids at $\delta 180.9$ and 179.4 (C-4 and C-5, respectively) instead of a ketone and an oxymethine in 7 , suggesting the opening of the planar macrocycle ring at C-4/C5. Four spin systems, as depicted in Figure 2, were highlighted through analysis of the COSY spectrum, with one of these suggesting the presence of a methyl senecioate unit, similar to 7. Most of the correlations observed in the HMBC spectrum were comparable to those of 7 (Figure 2), suggesting that $\mathbf{1 0}$ has the same carbon chain as compound 7 , including a tetrahydrofuran ring attached at C-11 and C-14, but with the two carboxylic acids at both ends of the carbon chain. The locations of the C-4 and C-5 carbonyl groups were determined from the HMBC correlations between $\mathrm{C}-4(\delta$ 180.9) and $\mathrm{H}-16$ $(\delta 1.24)$ and $\mathrm{H}-3\left(\delta_{\mathrm{H}} 3.13\right)$ and between $\mathrm{C}-5(\delta 179.4)$ and $\mathrm{H}-$ $6 a(\delta$ 2.20) and H-6b $(\delta$ 2.36). The cross-peak between H-8 and carbonyl $\mathrm{C}-1^{\prime}$ confirmed the link of the methyl senecioate unit at C-8. The trans configuration of the $\Delta^{1,2}$ double bond was confirmed by the large coupling constant value between $\mathrm{H}$ 1 and $\mathrm{H}-2(15.9 \mathrm{~Hz})$. The relative configuration of carbons $\mathrm{C}-$ $10, \mathrm{C}-11$, and C-14 was deduced from analysis of the ROESY spectrum of compound 10, but the configuration of the other carbons remained unknown due to the high molecular flexibility. Compound $\mathbf{1 0}$ was named tonantzitloic acid.

Compounds 11-15 were isolated from fractions F11, F12, and F14. They did not share the same MS/MS fragmentation pattern shown for the tonantzitlolone series, but instead, various losses of neutral fragments could be observed in the LC/MS experiments. The analysis of their NMR spectroscopic data indicated that these compounds possess a phorbol, a 4deoxyphorbol, or a 12-deoxyphorbol moiety. By comparison with NMR data reported in the literature, compounds 12 and 14 were identified as 12-O-acetylphorbol-13(2"-methyl)butyrate $(12)^{30}$ and 12-deoxyphorbol-13(2" -methyl)butyrate (14), ${ }^{31}$ whereas compounds 11,13 , and 15 are new.

Compound 11 showed a pseudomolecular ion at $\mathrm{m} / \mathrm{z}$ 497.2534 $[\mathrm{M}+\mathrm{Na}]^{+}$(calcd for $\left.\mathrm{C}_{27} \mathrm{H}_{38} \mathrm{O}_{7} \mathrm{Na}, 497.2515\right)$ in the HRESIMS, corresponding to the molecular formula $\mathrm{C}_{27} \mathrm{H}_{38} \mathrm{O}_{7}$. The NMR spectra of 11 showed typical signals for a $4 \alpha$ deoxyphorbol moiety, as apparent from the characteristic chemical shifts of protons H-1 $(\delta 7.01, \mathrm{~s}), \mathrm{H}-4(\delta 2.77, \mathrm{~m})$, $\mathrm{H}-5 \alpha(\delta 2.46 \mathrm{dd}, 15.5,5.0 \mathrm{~Hz}), \mathrm{H}-5 \beta(\delta 3.43 \mathrm{~d}, 15.5 \mathrm{~Hz})$, and H-7 ( $\delta 5.09$, brs). ${ }^{32}$ The ${ }^{13} \mathrm{C}$ NMR signals for two carbonyls at $\delta 170.7$ and 178.8 ( $\mathrm{C}-1^{\prime}$ and $\mathrm{C}-1^{\prime \prime}$, respectively) indicated the $4 \alpha$-deoxyphorbol moiety to be substituted by two ester side chains. In the HMBC spectrum, a correlation between $\mathrm{H}-12$ ( $\delta$ 5.41) and the ester carbonyl signal C- $1^{\prime}$ confirmed the acylation at C-12 by an acetate group. The values of the chemical shifts of the allylic protons $\mathrm{H}_{2}-20$ ( $\delta 3.88$ and 4.00) indicated the presence of a hydroxy group at $\mathrm{C}-20,{ }^{31}$ and the HMBC correlations between the proton resonance at $\delta 5.27$ (OH-9, exchangeable with $\left.\mathrm{D}_{2} \mathrm{O}\right)$ and $\mathrm{C}-1, \mathrm{C}-9$, and C-10 $(\delta 156.3,78.2$, and 47.6, respectively) indicated that a second hydroxy group is attached at C-9. Therefore, a second carbon chain could be connected to C-13 ( $\delta$ 65.0) through the ester carbonyl C-1" $(\delta$ 178.8). Finally, the HMBC correlation between H-2" ( $\delta$ 2.32) and $\mathrm{C}-1^{\prime \prime}$ together with ${ }^{1} \mathrm{H}-{ }^{1} \mathrm{H}$ COSY correlations that linked $\mathrm{H}-2^{\prime \prime}, \mathrm{H}-3^{\prime \prime} \alpha$ and $\beta, \mathrm{H}-4^{\prime \prime}$, and $\mathrm{H}-5^{\prime \prime}$ suggested the presence of a 2 "-methylbutyrate unit. Analysis of the ROESY spectrum of 11 confirmed the relative configuration of $\mathbf{1 1}$ as similar to a known $4 \alpha$-deoxyphorbol derivative. ${ }^{31}$ Thus, compound 11 was established as 12-O-acetyl-4 $\alpha$-deoxyphorbol-13(2"-methyl)butyrate. 
Table 3. Antimetabolic and Antiviral Activities of Compounds 1-15 in Vero Cells against CHIKV, SINV, and SFV

\begin{tabular}{|c|c|c|c|c|c|c|c|}
\hline \multirow[b]{2}{*}{ compound } & \multirow[b]{2}{*}{$\mathrm{CC}_{50}$ Vero $^{a}$} & \multicolumn{2}{|c|}{ CHIKV } & \multicolumn{2}{|c|}{ SINV } & \multicolumn{2}{|c|}{ SFV } \\
\hline & & $\mathrm{EC}_{50}{ }^{a}$ & $\mathrm{SI}^{b}$ & $\mathrm{EC}_{50}{ }^{a}$ & $\mathrm{SI}^{b}$ & $\mathrm{EC}_{50}{ }^{a}$ & $\mathrm{SI}^{b}$ \\
\hline 1 & $\mathrm{nd}^{c}$ & $>215$ & & $\mathrm{nd}^{c}$ & & $\mathrm{nd}^{c}$ & \\
\hline 2 & 122 & $12 \pm 3$ & 10.2 & 70 & 1.6 & $49 \pm 4$ & 2.5 \\
\hline 3 & $>210$ & $24 \pm 1$ & $>9$ & 109 & $>1.9$ & $>208$ & \\
\hline 4 & $\mathrm{nd}^{c}$ & $>222$ & & $\mathrm{nd}^{c}$ & & $\mathrm{nd}^{c}$ & \\
\hline 5 & $\mathrm{nd}^{c}$ & $>107$ & & $\mathrm{nd}^{c}$ & & $\mathrm{nd}^{c}$ & \\
\hline 6 & $56 \pm 6$ & $19 \pm 2$ & 3 & $41 \pm 5$ & 1.4 & 69 & 0.8 \\
\hline 7 & $>215$ & 168 & $>1.3$ & $\mathrm{nd}^{c}$ & & $\mathrm{nd}^{c}$ & \\
\hline 8 & $\mathrm{nd}^{c}$ & $>191$ & & $\mathrm{nd}^{c}$ & & $\mathrm{nd}^{c}$ & \\
\hline 9 & $\mathrm{nd}^{c}$ & $>208$ & & $\mathrm{nd}^{c}$ & & $\mathrm{nd}^{c}$ & \\
\hline 10 & $\mathrm{nd}^{c}$ & $>201$ & & $\mathrm{nd}^{c}$ & & $\mathrm{nd}^{c}$ & \\
\hline 11 & 105 & 77 & 1.4 & $\mathrm{nd}^{c}$ & & $\mathrm{nd}^{c}$ & \\
\hline 12 & 134 & $3.3 \pm 0.3$ & 41 & $>255$ & & $>255$ & \\
\hline 13 & $7.1 \pm 1.4$ & $1.4 \pm 0.2$ & 5.1 & $5.0 \pm 0.8$ & 1.4 & $>177$ & \\
\hline 14 & $>289$ & $1.2 \pm 0.2$ & $>240$ & $>289$ & & $>289$ & \\
\hline 15 & $13 \pm 1$ & $2.2 \pm 1.5$ & 5.9 & 11 & 1.2 & $>168$ & \\
\hline chloroquine & $89 \pm 28$ & $11 \pm 7$ & 8.1 & $11 \pm 2$ & 8.1 & $14 \pm 2$ & 6 \\
\hline
\end{tabular}

${ }^{a}$ Data in $\mu \mathrm{M}$. Values are the median \pm median absolute deviation calculated from at least three independent assays. ${ }^{b}$ SI or window for antiviral selectivity is calculated as $\mathrm{CC}_{50}$ Vero/EC $\mathrm{E}_{50} \mathrm{CHIKV}$, SINV, or SFV, respectively. ${ }^{c}$ nd $=$ not determined.

Table 4. Antimetabolic and Antiviral Activities of Compounds 11-15 in MT4 Cells against HIV-I (III ${ }_{B}$ ) and HIV-II (ROD)

\begin{tabular}{|c|c|c|c|c|c|c|}
\hline \multirow[b]{2}{*}{ compound } & \multicolumn{3}{|c|}{ HIV-I $\left(\mathrm{III}_{\mathrm{B}}\right)$} & \multicolumn{3}{|c|}{ HIV-II (ROD) } \\
\hline & $\mathrm{CC}_{50}(\mathrm{MT} 4)^{a}$ & $\mathrm{EC}_{50}{ }^{a}$ & $\mathrm{SI}^{b}$ & $\mathrm{CC}_{50}{ }^{a}$ & $\mathrm{EC}_{50}{ }^{a}$ & $\mathrm{SI}^{b}$ \\
\hline 11 & $85 \pm 18$ & $>85$ & & $57 \pm 27$ & $13 \pm 2$ & 4 \\
\hline 12 & 102 & $0.271 \pm 0.127$ & 376 & 102 & $0.107 \pm 0.035$ & 949 \\
\hline 13 & $8.4 \pm 0.9$ & $0.233 \pm 0.030$ & 36 & $5.7 \pm 1.7$ & $0.174 \pm 0.126$ & 33 \\
\hline 14 & 116 & $0.129 \pm 0.027$ & 899 & 116 & $0.056 \pm 0.020$ & 2056 \\
\hline 15 & $13 \pm 2$ & $0.043 \pm 0.003$ & 299 & $25 \pm 6$ & $0.018 \pm 0.003$ & 1431 \\
\hline nevirapine & $>15$ & $0.010 \pm 0.008$ & $>148$ & & $>15$ & \\
\hline lamivudine & $>87$ & $3.9 \pm 2.9$ & $>22$ & & $15.5 \pm 11.2$ & $>5.6$ \\
\hline azidothymidine & $>25$ & $0.0071 \pm 0.0004$ & $>3516$ & & $0.0060 \pm 0.0007$ & $>4176$ \\
\hline dideoxyinosine & $>50$ & $10.8 \pm 3.3$ & $>4.6$ & & $9.6 \pm 2.1$ & $>5.2$ \\
\hline
\end{tabular}

${ }^{a}$ Data in $\mu \mathrm{M}$. Values are the median \pm median absolute deviation calculated from at least three independent assays. ${ }^{b}$ SI or window for antiviral selectivity is calculated as $\mathrm{CC}_{50} \mathrm{MT}-4 / \mathrm{EC}_{50} \mathrm{HIV}$ ( $\mathrm{III}_{\mathrm{B}}$ or ROD).

The HRESIMS of compound $\mathbf{1 3}$ showed a pseudomolecular ion peak $[\mathrm{M}+\mathrm{Na}]^{+}$at $\mathrm{m} / z 589.3115$ (calcd 589.3141), which, in conjunction with the ${ }^{13} \mathrm{C}$ NMR data, was consistent with the molecular formula $\mathrm{C}_{34} \mathrm{H}_{46} \mathrm{O}_{7}$. Compound 13 provided spectroscopic data quite similar to those of 11. However, substantial modifications of the C-12 and C-13 acyl chains were evident. The $2^{\prime \prime}$-methylbutyrate group in $\mathbf{1 1}$ was found to be replaced by a butyrate unit, with the acetyl group replaced by a nine-membered aliphatic side chain including six conjugated olefinic protons at $\delta 5.60,6.63,7.41,6.48,6.21$, and $5.94\left(\mathrm{C}-2^{\prime}\right.$ to $\left.\mathrm{C}-7^{\prime}\right)$ linked to $\mathrm{C}-12$ through the carbonyl C-1' $(\delta$ 166.3). The cis/trans/trans configuration of the double bonds was determined by analysis of the coupling constants of the protons of the C-2'/C-7' spin system (see values in Table 2 ) together with correlations between $\mathrm{H}-2^{\prime \prime} / \mathrm{H}-3^{\prime \prime}, \mathrm{H}-3^{\prime \prime} / \mathrm{H}-5^{\prime \prime}, \mathrm{H}-4^{\prime \prime} / \mathrm{H}-6^{\prime \prime}$, and $\mathrm{H}-5^{\prime \prime} / \mathrm{H}-7^{\prime \prime}$ in the ROESY spectrum. The structure of 13 was established as $12 \beta-O$-[nona- $2 Z, 4 E, 6 E$-trienoyl]- $4 \alpha$-deoxyphorbol-13-butyrate.

Compound 15 showed a pseudomolecular ion at $\mathrm{m} / z$ 617.3472 $[\mathrm{M}+\mathrm{Na}]^{+}$(calcd for 617.3454) in the HRESIMS, corresponding to the molecular formula $\mathrm{C}_{36} \mathrm{H}_{50} \mathrm{O}_{7}$. Most of the NMR spectroscopic data were similar to those of 14 , indicating that compound 15 possesses the same $4 \beta$-phorbol moiety but with a different acyl chain attached at $\mathrm{C}-13$. The ${ }^{13} \mathrm{C}$ NMR spectroscopic data showed carbon resonances corresponding to six conjugated olefinic carbons at $\delta 124.0\left(\mathrm{C}-2^{\prime}\right), 144.4\left(\mathrm{C}-3^{\prime}\right)$, $137.4\left(\mathrm{C}-4^{\prime}\right), 138.8\left(\mathrm{C}-5^{\prime}\right), 140.2\left(\mathrm{C}-6^{\prime}\right)$, and $132.9\left(\mathrm{C}-7^{\prime}\right)$, a carbonyl at $\delta 200.8\left(\mathrm{C}-8^{\prime}\right)$, an ester carbonyl at $\delta 168.6$, and eight aliphatic carbons (one $\mathrm{CH}_{3}$ and seven $\mathrm{CH}_{2}$ ), forming a 16-membered aliphatic side chain. Analysis of the ${ }^{1} \mathrm{H}-{ }^{1} \mathrm{H}$ COSY and HMBC spectra supported the location of the three double bonds at C-2', C-4', and C- $6^{\prime}$ and the ketone at C- $8^{\prime}$. The all-trans configuration of the double bonds was determined by analysis of the coupling constants of the protons of the C$2^{\prime} / \mathrm{C}-7^{\prime}$ spin system (values in Table 2) together with correlations between $\mathrm{H}-2^{\prime \prime} / \mathrm{H}-4^{\prime \prime}, \mathrm{H}-4^{\prime \prime} / \mathrm{H}-6^{\prime \prime}, \mathrm{H}-3^{\prime \prime} / \mathrm{H}-5^{\prime \prime}$, and $\mathrm{H}-5^{\prime \prime} / \mathrm{H}-7^{\prime \prime}$ in the ROESY spectrum. The structure of $\mathbf{1 5}$ was therefore established as 12-deoxyphorbol-13-[8'-oxohexadeca-2E,4E,6E-trienoate].

The antiviral evaluation of compounds 1-15 was performed in virus-cell-based assays for three members of the genus alphavirus (CHIKV, SINV, and SFV), and the results are indicated in Table 3.

Phorbol esters 12 and 14 were found to be the most potent and selective inhibitors of CHIKV replication, as apparent from their lower $\mathrm{EC}_{50}$ values and higher selectivity indices $\left(\mathrm{EC}_{50}=\right.$ $3.3 \pm 0.3 \mu \mathrm{M}, \mathrm{SI}=41$ and $\mathrm{EC}_{50}=1.2 \pm 0.2 \mu \mathrm{M}, \mathrm{SI}>240$, respectively), whereas tonantzitlolones $\mathrm{B}, \mathrm{C}$, and $\mathrm{F}$ (2, 3, and 
6) showed only moderate inhibitory activity on CHIKV replication. No compound exhibited significant antiviral activity against the SINV and SFV viruses. From the results obtained, regarding the 4-deoxyphorbols 11 and 13 and the phorbol 12, it was observed that the presence of an $\mathrm{OH}-4 \beta$ group appears to be important for potent anti-CHIKV activity (12 vs 11 ), whereas the presence of an ester group at $\mathrm{C}-12$ with a $\mathrm{C}_{9}$-chain fatty acid increased the antimetabolic effect on Vero cells (13 vs 11). In addition, regarding the 12-deoxyphorbols 14 and 15, the presence of a long $\mathrm{C}_{16}$-chain fatty acid promoted a strong antimetabolic effect. These results confirmed previous observations made, showing that the 12-deoxyphorbol prostratin possesses a favorable anti-CHIKV profile. ${ }^{8}$

Since several phorbol esters have been reported to exhibit strong anti-HIV-1 activities, ${ }^{17,18,33}$ compounds $\mathbf{1 1 - 1 5}$ were investigated for selective antiviral activity against HIV type-1 $\left(\mathrm{III}_{\mathrm{B}}\right)$ and type-2 (ROD) lentiviruses. The results of this study are reported in Table 4. Compounds 12-15 showed a strong and selective antiviral effect on HIV-1 and HIV-2 virus replication, with $\mathrm{EC}_{50}$ values in the submicromolar range. These results are comparable to those obtained in the CHIKV assays and confirmed that a long-chain ester moiety located at the $\mathrm{C}-12$ or $\mathrm{C}-13$ position on the phorbol diterpene core increased the antimetabolic effect. Comparison of the results obtained for the 12-deoxyphorbols 14 and 15 (which were comparable to the data of Huang et $\mathrm{al}^{33}$ ) indicated that compound 14, having a shorter side chain at C-13, showed higher selectivity indices for HIV-1 as well as for the HIV-2 virus due to a weaker antimetabolic effect. To better understand the structure-activity relationships within the phorbol series, other compounds of phorbol- or 12-deoxyphorbol-type should be isolated and evaluated biologically in these assays.

In a previous study performed by Busch and colleagues, ${ }^{26}$ tonantzitlolones A (1) and B (2) were reported to show activity and selectivity against human kidney and breast cancer cell lines, but no $\mathrm{EC}_{50}$ values were provided. Tonantzitlolones 1-9 and tonantzitloic acid $\mathbf{1 0}$ were therefore subjected to cytotoxic assays against the HCT-116 (human colon carcinoma), MCF-7 (human breast adenocarcinoma), and PC3 (human prostate) cancer cell lines. At $1 \mu \mathrm{M}$, none of the compounds had an inhibitory activity over $40 \%$ on the three cancer cell lines, whereas at $10 \mu \mathrm{M}$ compounds $\mathbf{2}-\mathbf{6}$ showed inhibition activities of $49,50,47,61$, and $68 \%$ for HCT-116 cells and 35, 41, 20, 49, and $40 \%$ for PC3 cells, respectively.

\section{EXPERIMENTAL SECTION}

General Experimental Procedures. Optical rotations were measured at $25{ }^{\circ} \mathrm{C}$ on an Anton Paar MCP 300 polarimeter. UV spectra were recorded on a Varian Cary $100 \mathrm{UV}$-vis spectrophotometer. NMR spectra were recorded in $\mathrm{CDCl}_{3}$ on a Bruker $600 \mathrm{MHz}$ instrument (Avance 600) using a $1.7 \mathrm{~mm}$ microprobe for compounds 4, 5, 7 to 10 , and 12 to 15 , on a Bruker $500 \mathrm{MHz}$ instrument (Avance 500) for plant extracts, fractions, and compounds 6 and 11, and on a Bruker $300 \mathrm{MHz}$ instrument (Avance 300) for compounds 1 to 3 . Chemical shifts (relative to TMS) are in ppm, and coupling constants are in Hz. SunFire analytical and preparative $\mathrm{C}_{18}$ columns $(250 \times 4.6$ $\mathrm{mm}$ and $250 \times 19 \mathrm{~mm}$ i.d.; $10 \mu \mathrm{m}$ Waters) and a Nucleodur PFP analytical column $(250 \times 4,6 \mathrm{~mm}$ i.d.; $5 \mu \mathrm{m}$ Macherey-Nagel $)$ were used for HPLC separations using a Dionex system equipped with a sample manager (Gilson 215 liquid handler), a column fluidics organizer, a binary pump (Dionex HPG-3200BX), a UV-vis diode array detector (190-600 nm, Dionex UVD340U), and a PL-ELS 1000 ELSD Polymer Laboratory detector. All solvents were purchased from Carlo Erba (France), and analytical plates (Si gel 60 F254) were from Merck (France). Prepacked GraceResolv silica cartridges were used for flash chromatography using a Teledyne Isco Combiflash Rf 200i. HRESIMS data were acquired using an Acquity Waters UPLC coupled to a Waters LCT Premier XE mass spectrometer. The UPLC system was equipped with a Waters Acquity PDA dectector. Separation was achieved on a $\mathrm{BEHC}_{18}$ column $(1.7 \mu \mathrm{m}, 2.1 \mathrm{~mm} \times 50 \mathrm{~mm})$ at a flow rate of $0.6 \mathrm{~mL} / \mathrm{min}$. Elution was conducted with a $\mathrm{H}_{2} \mathrm{O}-\mathrm{CH}_{3} \mathrm{CN}+$ $0.1 \%$ formic acid gradient as follows: $95: 5$ to $0: 100$ in $5.5 \mathrm{~min}$. The ionization was carried out using an electrospray ionization source in the positive mode (range $80-1500 \mathrm{~m} / \mathrm{z}$ ).

Plant Material. Leaves of Stillingia lineata were collected in November 2009 in Langevin (La Réunion, France) and authenticated by Prof. Dominique Strasberg (University of La Réunion). A voucher specimen (RUN-100) has been deposited at the LCSNSA of the University of La Réunion.

Extraction and Isolation. The dried leaves $(224.2 \mathrm{~g})$ of $S$. lineata were extracted with EtOAc $(3 \times 500 \mathrm{~mL})$ to yield a crude extract $(5.7$ g) after concentration in vacuo at $40{ }^{\circ} \mathrm{C}$. This extract was dissolved in $250 \mathrm{~mL}$ of acetonitrile and subjected to a liquid/liquid partition with $n$-heptane $(3 \times 250 \mathrm{~mL})$ to afford $1.9 \mathrm{~g}$ of a MeCN-soluble fraction. This residue was subjected to silica gel column chromatography using a gradient of $n$-heptane-EtOAc- $\mathrm{MeOH}$ of increasing polarities (1:0:0 to $0: 1: 0$ to $0: 8: 2,50 \mathrm{~mL} / \mathrm{min}$ ) to afford 20 fractions, $\mathrm{F} 1-\mathrm{F} 20$, according to their TLC profiles. F1 $(60.1 \mathrm{mg})$ was purified by preparative HPLC (SunFire $\mathrm{C}_{18}, \mathrm{MeCN}-\mathrm{H}_{2} \mathrm{O} 90: 10+0.1 \%$ formic acid at $20 \mathrm{~mL} / \mathrm{min})$ to afford compounds $1(26.3 \mathrm{mg})$ and $4(1.3 \mathrm{mg})$ $\left(t_{\mathrm{R}} 8.0\right.$ and $6.5 \mathrm{~min}$, respectively). Fraction F3 $(96.2 \mathrm{mg})$ was subjected to preparative HPLC (SunFire $\mathrm{C}_{18}, \mathrm{MeCN}-\mathrm{H}_{2} \mathrm{O}(80: 20)+0.1 \%$ formic acid at $20 \mathrm{~mL} / \mathrm{min})$ to yield compound $2(29.4 \mathrm{mg})\left(t_{\mathrm{R}} 14.0\right.$ $\mathrm{min})$. Purification of fraction F10 $(70 \mathrm{mg})$ by preparative HPLC (SunFire $\mathrm{C}_{18}, \mathrm{MeCN}-\mathrm{H}_{2} \mathrm{O}+0.1 \%$ formic acid, 65:35 to 100:0, in 20 min, $20 \mathrm{~mL} / \mathrm{min})$ afforded a mixture of F10-1 (2.7 mg) and compound $3(6.6 \mathrm{mg})\left(t_{\mathrm{R}} 7.0\right.$ and $13.5 \mathrm{~min}$, respectively). F10-1 (2.7 $\mathrm{mg}$ ) was separated by analytical HPLC (Nucleodur PFP, $\mathrm{MeCN}-\mathrm{H}_{2} \mathrm{O}$ $(50: 50)+0.1 \%$ formic acid at $1 \mathrm{~mL} / \mathrm{min})$, leading to compound $8(0.9$ $\mathrm{mg})\left(t_{\mathrm{R}} 13.0 \mathrm{~min}\right) . \mathrm{F} 11(79.8 \mathrm{mg})$ was purified by preparative HPLC (SunFire $\mathrm{C}_{18}, \mathrm{MeCN}-\mathrm{H}_{2} \mathrm{O}+0.1 \%$ formic acid, 45:55 to 100:0, at 20 $\mathrm{mL} / \mathrm{min}$ ) to afford a mixture of F11-1 to -3 and compounds 5 (1.0 $\mathrm{mg}), 3(1.8 \mathrm{mg})$, and $6(2.9 \mathrm{mg})\left(t_{\mathrm{R}} 14.5,16.0,27.0,21.5,22.5\right.$, and $23.5 \mathrm{~min}$, respectively). F11-1 (0.8 mg) was separated by analytical HPLC (Nucleodur PFP, MeCN- $\mathrm{H}_{2} \mathrm{O}(45: 55)+0.1 \%$ formic acid at 1 $\mathrm{mL} / \mathrm{min})$, leading to compound $9(0.2 \mathrm{mg})\left(t_{\mathrm{R}} 14.5 \mathrm{~min}\right) . \mathrm{F} 11-2(3$ $\mathrm{mg}$ ) was separated by analytical HPLC (Nucleodur PFP, $\mathrm{MeCN}-\mathrm{H}_{2} \mathrm{O}$ $(55: 45)+0.1 \%$ formic acid at $1 \mathrm{~mL} / \mathrm{min})$, affording compound 10 $(0.7 \mathrm{mg})\left(t_{\mathrm{R}} 8.0 \mathrm{~min}\right)$. Purification of fraction F11-3 $(2.3 \mathrm{mg})$ by analytical HPLC (Nucleodur PFP, $\mathrm{MeCN}-\mathrm{H}_{2} \mathrm{O}(65: 35)+0.1 \%$ formic acid at $1 \mathrm{~mL} / \mathrm{min})$ furnished compound $13(0.5 \mathrm{mg})\left(t_{\mathrm{R}} 12.0\right.$ $\mathrm{min})$. Fraction F12 (114.3 mg) was subjected to preparative HPLC (SunFire $\mathrm{C}_{18}, \mathrm{MeCN}-\mathrm{H}_{2} \mathrm{O}+0.1 \%$ formic acid, 50:50 to 100:0, in 20 $\mathrm{min}$ at $20 \mathrm{~mL} / \mathrm{min})$ to yield compounds $11(1.3 \mathrm{mg})$ and $6(1.2 \mathrm{mg})$ $\left(t_{\mathrm{R}} 12.5\right.$ and $21.0 \mathrm{~min}$, respectively). Purification of fraction F6 (21.7 $\mathrm{mg}$ ) by preparative HPLC (SunFire $\mathrm{C}_{18}, \mathrm{MeCN}-\mathrm{H}_{2} \mathrm{O}(60: 40)+0.1 \%$ formic acid, $20 \mathrm{~mL} / \mathrm{min})$ afforded compound $7(0.7 \mathrm{mg})\left(t_{\mathrm{R}} 16.0\right.$ $\mathrm{min}$ ). F14 $\left(80 \mathrm{mg}\right.$ ) was purified by preparative HPLC (SunFire $\mathrm{C}_{18}$, $\mathrm{MeCN}-\mathrm{H}_{2} \mathrm{O}+0.1 \%$ formic acid, $50: 50$ to $100: 0$, in $25 \mathrm{~min}$ at $20 \mathrm{~mL} /$ $\mathrm{min})$ to afford a mixture of F14-1 (1.5 mg) and compound 15 (0.4 $\mathrm{mg})\left(t_{\mathrm{R}} 10.0\right.$ and $22.5 \mathrm{~min}$, respectively). F14-1 ( $\left.1.5 \mathrm{mg}\right)$ was further separated by analytical HPLC (Sunfire $\mathrm{C}_{18}, \mathrm{MeCN}-\mathrm{MeOH}(1: 1)-$ $\mathrm{H}_{2} \mathrm{O}(75: 25)$ at $\left.1 \mathrm{~mL} / \mathrm{min}\right)$, leading to compounds $14(0.4 \mathrm{mg})$ and $12(0.3 \mathrm{mg})\left(t_{\mathrm{R}} 7.5\right.$ and $10.0 \mathrm{~min}$, respectively).

Tonantzitlolone D (4): colorless oil; $[\alpha]_{\mathrm{D}}^{24}+120\left(\right.$ c 0.1, $\left.\mathrm{CHCl}_{3}\right)$; $\mathrm{UV}\left(\mathrm{CH}_{2} \mathrm{Cl}_{2}\right) \lambda_{\max }(\log \varepsilon) 230(3.90) \mathrm{nm} ;{ }^{1} \mathrm{H}$ and ${ }^{13} \mathrm{C} \mathrm{NMR}$, see Table 1; HRESIMS $m / z 473.2523[\mathrm{M}+\mathrm{Na}]^{+}$(calcd for $\mathrm{C}_{25} \mathrm{H}_{38} \mathrm{O}_{7} \mathrm{Na}$, 473.2515).

Tonantzitlolone $E$ (5): colorless oil; $[\alpha]_{\mathrm{D}}^{24}+108\left(c\right.$ o.1, $\left.\mathrm{CHCl}_{3}\right)$; $\mathrm{UV}\left(\mathrm{CH}_{2} \mathrm{Cl}_{2}\right) \lambda_{\max }(\log \varepsilon) 229(3.88) \mathrm{nm} ;{ }^{1} \mathrm{H}$ and ${ }^{13} \mathrm{C} \mathrm{NMR}$, see Table 1; HRESIMS $m / z 489.2482[\mathrm{M}+\mathrm{Na}]^{+}$(calcd for $\mathrm{C}_{25} \mathrm{H}_{38} \mathrm{O}_{8} \mathrm{Na}$, 489.2464).

Tonantzitlolone $F$ (6): colorless oil; $[\alpha]_{\mathrm{D}}^{24}+76\left(c 0.1, \mathrm{CHCl}_{3}\right)$; UV $\left(\mathrm{CH}_{2} \mathrm{Cl}_{2}\right) \lambda_{\max }(\log \varepsilon) 264(3.53), 307(3.51) \mathrm{nm} ;{ }^{1} \mathrm{H}$ and ${ }^{13} \mathrm{C}$ NMR, 
see Table 1 ; HRESIMS $m / z$ 474.2461 $[\mathrm{M}+\mathrm{H}]^{+}$(calcd for $\mathrm{C}_{26} \mathrm{H}_{36} \mathrm{NO}_{7}, 474.2492$ ).

Tonantzitlolone $\mathrm{G}$ (7): colorless oil; $[\alpha]_{\mathrm{D}}^{24}+140\left(c 0.1, \mathrm{CHCl}_{3}\right)$; $\mathrm{UV}\left(\mathrm{CH}_{2} \mathrm{Cl}_{2}\right) \lambda_{\max }(\log \varepsilon) 229(3.82) \mathrm{nm} ;{ }^{1} \mathrm{H}$ and ${ }^{13} \mathrm{C}$ NMR, see Table 1; HRESIMS $m / z 487.2664[\mathrm{M}+\mathrm{Na}]^{+}$(calcd for $\mathrm{C}_{26} \mathrm{H}_{40} \mathrm{O}_{7} \mathrm{Na}$, 487.2672).

Tonantzitlolone $H$ (8): colorless oil; $[\alpha]^{24}{ }_{\mathrm{D}}+74\left(c 0.1, \mathrm{CHCl}_{3}\right)$; UV $\left(\mathrm{CH}_{2} \mathrm{Cl}_{2}\right) \lambda_{\max }(\log \varepsilon) 228(3.90) \mathrm{nm} ;{ }^{1} \mathrm{H}$ and ${ }^{13} \mathrm{C}$ NMR, see Table 1; HRESIMS $\mathrm{m} / z$ 545.2724 $[\mathrm{M}+\mathrm{Na}]^{+}$(calcd for $\mathrm{C}_{28} \mathrm{H}_{42} \mathrm{O}_{9} \mathrm{Na}$, 545.2727).

Tonantzitlolone I (9): colorless oil; $[\alpha]_{\mathrm{D}}^{24}+24\left(\mathrm{c} 0.05, \mathrm{CHCl}_{3}\right)$; UV $\left(\mathrm{CH}_{2} \mathrm{Cl}_{2}\right) \lambda_{\max }(\log \varepsilon) 229(3.95) \mathrm{nm} ;{ }^{1} \mathrm{H}$ and ${ }^{13} \mathrm{C}$ NMR, see Table 1 ; HRESIMS $m / z 503.2635[\mathrm{M}+\mathrm{Na}]^{+}$(calcd for $\mathrm{C}_{26} \mathrm{H}_{40} \mathrm{O}_{8} \mathrm{Na}$, 503.2621).

Tonantzitloic acid (10): colorless oil; $[\alpha]^{24}-38\left(c 0.05, \mathrm{CHCl}_{3}\right)$; UV $\left(\mathrm{CH}_{2} \mathrm{Cl}_{2}\right) \lambda_{\max }(\log \varepsilon) 229(4.01) \mathrm{nm} ;{ }^{1} \mathrm{H}$ and ${ }^{13} \mathrm{C}$ NMR, see Table 1; HRESIMS $m / z 519.2557[\mathrm{M}+\mathrm{Na}]^{+}\left(\right.$calcd for $\mathrm{C}_{26} \mathrm{H}_{40} \mathrm{O}_{9} \mathrm{Na}$, 519.2570)

12-O-Acetyl-4 $\alpha$-deoxyphorbol-13-(2"-methyl)butyrate (11): colorless oil; $[\alpha]_{\mathrm{D}}^{24}-20\left(c 0.1, \mathrm{CHCl}_{3}\right) ; \mathrm{UV}\left(\mathrm{CH}_{2} \mathrm{Cl}_{2}\right) \lambda_{\max }(\log \varepsilon) 230$ (4.22) $\mathrm{nm} ;{ }^{1} \mathrm{H}$ and ${ }^{13} \mathrm{C}$ NMR, see Table 2; HRESIMS $\mathrm{m} / z$ 497.2534 $[\mathrm{M}+\mathrm{Na}]^{+}$(calcd for $\left.\mathrm{C}_{27} \mathrm{H}_{38} \mathrm{O}_{7} \mathrm{Na}, 497.2515\right)$.

$12 \beta$-O-[Nona-2Z,4E,6E-trienoyl]-4 $\alpha$-deoxyphorbol-13-butyrate (13): colorless oil; $[\alpha]^{24}-30\left(c 0.1, \mathrm{CHCl}_{3}\right)$; UV $\left(\mathrm{CH}_{2} \mathrm{Cl}_{2}\right) \lambda_{\max }(\log$ ع) 233 (3.87), 308 (4.19) nm; ${ }^{1} \mathrm{H}$ and ${ }^{13} \mathrm{C}$ NMR, see Table 2; HRESIMS $m / z$ 589.3115 $[\mathrm{M}+\mathrm{Na}]^{+}$(calcd for $\mathrm{C}_{34} \mathrm{H}_{46} \mathrm{O}_{7} \mathrm{Na}$, 589.3141).

12-Deoxyphorbol-13-[8'-oxohexadeca-2E,4E,6E-trienoate] (15): colorless oil; $[\alpha]^{24}{ }_{\mathrm{D}}+40\left(c 0.1, \mathrm{CHCl}_{3}\right)$; UV $\left(\mathrm{CH}_{2} \mathrm{Cl}_{2}\right) \lambda_{\max }(\log \varepsilon)$ 202 (4.45), 314 (4.98) nm; ${ }^{1} \mathrm{H}$ and ${ }^{13} \mathrm{C}$ NMR, see Table 2; HRESIMS $\mathrm{m} / z$ 617.3472 $[\mathrm{M}+\mathrm{Na}]^{+}$(calcd for $\mathrm{C}_{36} \mathrm{H}_{50} \mathrm{O}_{7} \mathrm{Na}, 617.3454$ ).

Virus-Cell-Based Anti-alphavirus Assay. The antiviral experiments have been performed in a biosafety screening facility that has been validated for handling chikungunya virus as well as the manipulation of molecules of unknown chemical safety risk. All studies have been performed by trained staff. Throughout the experiments, Vero (African green monkey kidney) cells were used. The following viruses were used: Chikungunya virus strain 899, Sindbis virus strain HRsp, and Semliki Forest virus strain Vietnam. Serial dilutions of the initial plant extracts, fractions, or compounds, as well as the reference compound, chloroquine, were prepared in assay medium [MEM Reg3 (cat. no. 19993013; Invitrogen), 2\% FCS (Integro), $5 \mathrm{~mL}$ of $200 \mathrm{mM}$ L-glutamine, and $5 \mathrm{~mL}$ of $7.5 \%$ sodium bicarbonate] and were added to empty wells of a 96-well microtiter plate (Falcon, BD). Subsequently, $50 \mu \mathrm{L}$ of a $4 \times$ virus dilution in assay medium was added, followed by $50 \mu \mathrm{L}$ of a cell suspension. This suspension, with a cell density of 25000 cells $/ 50 \mu \mathrm{L}$, was prepared from a Vero cell line subcultured in cell growth medium (MEM Reg3 supplemented with $10 \%$ FCS, $5 \mathrm{~mL}$ of L-glutamine, and $5 \mathrm{~mL}$ of sodium bicarbonate) at a ratio of 1:4 and grown for 7 days in $150 \mathrm{~cm}^{2}$ tissue culture flasks (Techno Plastic Products). The assay plates were returned to the incubator for 6 or 7 days $\left(37^{\circ} \mathrm{C}, 5 \% \mathrm{CO}_{2}, 95-99 \%\right.$ relative humidity), a time at which maximal virus-induced cell death or cytopathic effect was observed in untreated, infected controls.

Subsequently, the assay medium was aspirated, replaced with $75 \mu \mathrm{L}$ of a 5\% MTS (Promega) solution in phenol red-free medium, and incubated for $1.5 \mathrm{~h}$. Absorbance was measured at a wavelength of 498 $\mathrm{nm}$ (Safire2, Tecan); optical densities (OD values) reached $0.6-0.8$ for the untreated, uninfected controls. Raw data were converted to percentages of controls, and the $\mathrm{EC}_{50}$ (50\% effective concentration, or concentration that is calculated to inhibit virus-induced cell death by $50 \%)$ and $\mathrm{CC}_{50}(50 \%$ antimetabolic concentration, or concentration that is calculated to inhibit the overall cell metabolism by 50\%) values were derived from the dose-response curves. All assay conditions producing an antiviral effect that exceeded 50\% were checked microscopically for minor signs of a cytopathic effect or adverse effects on the host cell (i.e., altered cell morphology). A compound was considered to elicit a selective antiviral effect on virus replication only when, following microscopic quality control, at least at one concentration of compound no cytopathic or any adverse effect is observed (image resembling untreated, uninfected cells). Multiple, independent experiments were performed.

Virus Cell-Based Anti-HIV Assay. Evaluation of the antiviral activity of the test compounds against HIV-1 strain $\left(\mathrm{III}_{\mathrm{B}}\right)$ and HIV-2 strain (ROD) in MT-4 cells was performed using the MTT assay, as previously described. ${ }^{34}$ Stock solutions (109 final concentration) of the test compounds were added in $25 \mu \mathrm{L}$ volumes to two series of triplicate wells to allow simultaneous evaluation of their effects on mock- and HIV-infected cells at the beginning of each experiment. Serial 5 -fold dilutions of test compounds were made directly in flatbottomed 96-well microtiter trays using a Biomek 3000 robot (Beckman Instruments, Fullerton, CA, USA). Untreated control HIV- and mock-infected cell samples were included for each sample. HIV-1 $\left(\mathrm{III}_{\mathrm{B}}\right)$ or HIV-2 (ROD) stock $(50 \mu \mathrm{L})$ at $100-300 \mathrm{CCIC}_{50}$ ( $50 \%$ cell culture infectious dose) or culture medium was added to microtiter tray wells. Mock-infected cells were used to evaluate the effect of test compound on uninfected cells in order to assess the cytotoxicity of the test compound. Exponentially growing MT-4 cells were centrifuged for $5 \mathrm{~min}$ at $1000 \mathrm{rpm}$, and the supernatant was discarded. The MT-4 cells were resuspended at $66 \times 10^{5}$ cells $/ \mathrm{mL}$, and an amount of $50 \mu \mathrm{L}$ volume was transferred to the microtiter tray wells. Five days after infection, the viability of mock- and HIV-infected cells was examined spectrophotometrically by the MTT assay. The MTT assay is based on the reduction of yellow 3-(4,5-dimethylthiazol2-yl)-2,5-diphenyltetrazolium bromide (MTT) (Across Organics, Geel, Belgium) by mitochondrial dehydrogenase of metabolically active cells to a blue-purple formazan that can be measured spectrophotometrically. The absorbances were read in an eightchannel computer-controlled photometer (Multiscan Ascent Reader, Labsystem, Helsinki, Finland) at two wavelengths (540 and $690 \mathrm{~nm}$ ). All data have been calculated using the median OD value of three wells.

Cell Culture and Proliferation Assay. Cancer cell lines were obtained from the American Type Culture Collection (Rockville, MD, USA) and were cultured according to the supplier's instructions. Human HCT-116 colorectal carcinoma and PC3 prostate adenocarcinoma cells were grown in RPMI 1640 supplemented with $10 \%$ fetal calf serum (FCS) and 1\% glutamine. MCF-7 breast adenocarcinoma cells were grown in DMEM supplemented with $10 \%$ FCS and $1 \%$ glutamine. Cell lines were maintained at $37{ }^{\circ} \mathrm{C}$ in a humidified atmosphere containing $5 \% \mathrm{CO}_{2}$. Cell growth inhibition was determined by an MTS assay according to the manufacturer's instructions (Promega, Madison, WI, USA). Briefly, the cells were seeded in 96-well plates $\left(2.5 \times 10^{3}\right.$ cells/well $)$ containing $200 \mu \mathrm{L}$ of growth medium. After $24 \mathrm{~h}$ of culture, the cells were treated with the tested compounds at 1 and $10 \mu \mathrm{M}$ final concentrations. After $72 \mathrm{~h}$ of incubation, $40 \mu \mathrm{L}$ of resazurin was added for $2 \mathrm{~h}$ before recording absorbance at $490 \mathrm{~nm}$ with a spectrophotometric plate reader. The percent cytotoxicity index $\left[\left(\mathrm{OD}_{490}\right.\right.$ treated $/ \mathrm{OD}_{490}$ control $\left.) \times 100\right]$ was calculated from three experiments. Taxotère $\left(\mathrm{IC}_{50}\right.$ 's: $5 \times 10^{-8} \mathrm{M}$ and 2 $\times 10^{-9} \mathrm{M}$ for HCT-116 and PC3 cell lines, respectively) and vinblastine $\left(\mathrm{IC}_{50}: 5 \times 10^{-9} \mathrm{M}\right.$ for MCF-7 cell line) were used as positive controls.

\section{ASSOCIATED CONTENT}

\section{Supporting Information}

1D- and 2D-NMR spectra and HRESIMS data for compounds 4 $\mathbf{- 1 2}$ and 14. The Supporting Information is available free of charge on the ACS Publications website at DOI: 10.1021/ acs.jnatprod.5b00116.

\section{AUTHOR INFORMATION}

\section{Corresponding Author}

*Tel: + 331698230 85. Fax: + 331690772 47. E-mail: marc.litaudon@cnrs.fr.

\section{Notes}

The authors declare no competing financial interest. 


\section{ACKNOWLEDGMENTS}

This work was supported by the Centre de Recherche et de Veille des Maladies Émergentes dans l'Océan Indien (CRVOI), by the Regional Council of La Réunion, and by the European Regional Development Fund (ERDF). The authors are very grateful to E. Boyer and D. Strasberg (UMR C_53 PVBMT) for their contribution to plant material identification and species collection. This work has also benefited from an "Investissement d'Avenir" grant managed by Agence Nationale de la Recherche (CEBA, ref ANR-10-LABX-25-01). We also would like to acknowledge C. Collard, N. Verstraeten, and C. Vanderheydt for their excellent technical assistance in the acquisition of the antiviral data and Dr. J. Bignon and Mrs. H. Levaique, who performed the cytotoxic assays.

\section{REFERENCES}

(1) Fischer, D.; Thomas, S.; Suk, J.; Sudre, B.; Hess, A.; Tjaden, N.; Beierkuhnlein, C.; Semenza, J. Int. J. Health Geogr. 2013, 12, 51-62.

(2) Hunter, P. R. In Encyclopedia of Environmental Health; Nriagu, J. O., Ed.; Elsevier: Burlington, 2011; pp 637-644.

(3) Caglioti, C.; Lalle, E.; Castilletti, C.; Carletti, F.; Capobianchi, M. R.; Bordi, L. New Microbiol. 2013, 36, 211-227.

(4) Rezza, G. In Emerging Infectious Diseases; Ergynil, I.; Can, F.; Madoff, L.; Akova, M., Eds.; Academic Press: Amsterdam, 2014; pp 163-174.

(5) Allard, P.-M.; Leyssen, P.; Martin, M.-T.; Bourjot, M.; Dumontet, V.; Eydoux, C.; Guillemot, J.-C.; Canard, B.; Poullain, C.; Guéritte, F.; Litaudon, M. Phytochemistry 2012, 84, 160-168.

(6) Allard, P.-M.; Martin, M.-T.; Tran Huu Dau, M.-E.; Leyssen, P.; Guéritte, F.; Litaudon, M. Org. Lett. 2011, 14, 342-345.

(7) Bourjot, M.; Leyssen, P.; Neyts, J.; Dumontet, V.; Litaudon, M. Molecules 2014, 19, 3617-3627.

(8) Bourjot, M.; Delang, L.; Nguyen, V. H.; Neyts, J.; Guéritte, F.; Leyssen, P.; Litaudon, M. J. Nat. Prod. 2012, 75, 2183-2187.

(9) Corlay, N.; Delang, L.; Girard-Valenciennes, E.; Neyts, J.; Clerc, P.; Smadja, J.; Guéritte, F.; Leyssen, P.; Litaudon, M. Fitoterapia 2014, 97, 87-91.

(10) Nothias-Scaglia, L.-F.; Retailleau, P.; Paolini, J.; Pannecouque, C.; Neyts, J.; Dumontet, V.; Roussi, F.; Leyssen, P.; Costa, J.; Litaudon, M. J. Nat. Prod. 2014, 77, 1505-1512.

(11) Ersvaer, E.; Kittang, A. O.; Hampson, P.; Sand, K.; Gjertsen, B. T.; Lord, J. M.; Bruserud, O. Toxins 2010, 2, 174-194.

(12) Mwine, T. J.; Van Damme, P. J. Med. Plants Res. 2011, 5, 652662.

(13) Vasas, A.; Hohmann, J. Chem. Rev. 2014, 114, 8579-8612.

(14) Vasas, A.; Rédei, D.; Csupor, D.; Molnár, J.; Hohmann, J. Eur. J. Org. Chem. 2012, 2012, 5115-5130.

(15) Duran-Pena, M. J.; Botubol Ares, J. M.; Collado, I. G.; Hernandez-Galan, R. Nat. Prod. Rep. 2014, 31, 940-952.

(16) Bedoya, L. M.; Marquez, N.; Martinez, N.; Gutierrez-Eisman, S.; Alvarez, A.; Calzado, M. A.; Rojas, J. M.; Appendino, G.; Muñoz, E.; Alcami, J. Biochem. Pharmacol. 2009, 77, 965-978.

(17) El-Mekkawy, S.; Meselhy, M. R.; Nakamura, N.; Hattori, M.; Kawahata, T.; Otake, T. Phytochemistry 2000, 53, 457-464.

(18) Marquez, N.; Calzado, M. A.; Sanchez-Duffhues, G.; Perez, M. S.; Minassi, A.; Pagani, A.; Appendino, G.; Diaz, L.; Munoz-Fernandez, M. A.; Munoz, E. Biochem. Pharmacol. 2008, 75, 1370-1380.

(19) Leyssen, P.; Smadja, J.; Rasoanaivo, P.; Gurib-Fakim, A.; Mahomoodally, M. F.; Canard, B.; Guillemot, J.-C.; Litaudon, M.; Guéritte, F. In Novel Plant Bioresources; John Wiley \& Sons, Ltd.: Chichester, West Sussex, UK, 2014; pp 151-161.

(20) Chapuis, J.-C.; Sordat, B.; Hostettmann, K. J. Ethnopharmacol. 1988, 23, 273-284.

(21) Sequeiros, C.; Lopez, L. M. I.; Caffini, N. O.; Natalucci, C. L. Fitoterapia 2003, 74, 570-577.
(22) Cota, B. B.; Johann, S.; Oliveira, D. M.; Siqueira, E. P.; SouzaFagundes, E. M.; Cisalpino, P. S.; Alves, T. M. A.; Zani, C. L. Rev. Bras. Farmacogn. 2011, 21, 70-77.

(23) http://www.mskcc.org/cancer-care/herb/stillingia.

(24) Adolf, W.; Hecker, E. Tetrahedron Lett. 1980, 21, 2887-2890.

(25) Dräger, G.; Jeske, F.; Kunst, E.; Lopez, E. G.; Sanchez, H. V.; Tsichritzis, F.; Kirschning, A.; Jakupovic, J. Eur. J. Org. Chem. 2007, 5020-5026.

(26) Busch, T.; Schuster, H.; Kirschning, A. Tetrahedron Lett. 2008, $49,5273-5275$.

(27) Lima, M. A. A.; Lima, J. Q.; Arriaga, A. M. C.; Andrade-Neto, M.; Santiago, G. M. P.; Bezerra, B. P.; Fereira, Y. S.; Veras, H. N. H.; Braz-Filho, R. Quím. Nova 2009, 32, 348-353.

(28) Techer, S. Criblage d'activités biologiques de plantes endémiques ou indigènes de La Réunion - Recherche de molécules antivirales ciblant le virus du chikungunya. Ph.D. Thesis, Université de La Réunion, St Denis, La Réunion, 2013.

(29) Xu, J.; Xie, C.; Jin, D.-q.; Guo, Y.; Zhao, P.; Wang, S.; He, Y. Phytochem. Lett. 2012, 5, 713-716.

(30) Ma, Y. Chinese Patent CN20101533709 20101108, 2011.

(31) Gschwendt, M.; Hecker, E. Tetrahedron Lett. 1969, 10, 35093512.

(32) Marco, J. A.; Sanz-Cervera, J. F.; Checa, J.; Palomares, E.; Fraga, B. M. Phytochemistry 1999, 52, 479-485.

(33) Huang, S.-Z.; Zhang, X.; Ma, Q.-Y.; Peng, H.; Zheng, Y.-T.; Hu, J.-M.; Dai, H.-F.; Zhou, J.; Zhao, Y.-X. Fitoterapia 2014, 95, 34-41.

(34) Pauwels, R.; Balzarini, J.; Baba, M.; Snoeck, R; Schols, D.; Herdewijn, P.; Desmyter, J.; De Clercq, E. J. Virol. Methods 1988, 20, 309-321. 